\title{
4. Lekfolkets bilder i Vadstena klosterkyrka
}

\section{Besökarna i Vadstena klosterkyrka}

Det fanns olika anledningar till att besöka Vadstena kloster. Det stora flertalet kyrkobesökare var lekfolk som av olika skäl gjorde en pilgrimsvandring dit. Trots mängden av folk som passerade under medeltiden hör lekfolkets roll i Vadstena paradoxalt nog till det som kanske utforskats minst. Detta trots att det finns en omfattande internationell forskning kring medeltidens pilgrimsväsende och hur man betedde sig som pilgrim. ${ }^{624}$ Mycket av denna forskning handlar emellertid om vilka vägar man reste och hur, men varken vägarna eller färdsätten till Vadstena är relevanta i denna mer platsfokuserade bildbruksstudie, och kommer därför inte att diskuteras nedan.

Som konstaterades i inledningen till förra kapitlet var brödernas funktion i klostret huvudsakligen att vara till för systrarnas andliga välfärd, men att de också hade ytterligare en viktig uppgift, nämligen att predika för klosterkyrkans besökare. ${ }^{625}$ Heliga Birgitta var angelägen om att nå ut med det kristna budskapet till alla samhällsklasser och då spelade brödernas predikningar en viktig roll. Att döma av den mängd predikningar från Vadstena som bevarats till idag var det en uppgift som togs på allvar av bröderna. ${ }^{626}$ På något vis måste heliga Birgitta faktiskt ha räknat med att det verkligen skulle komma många människor till Vadstena, även om hon rimligen inte förutsåg sin egen centrala roll som pilgrimsmål. Hon gav uttryckligen också möjlighet för lekfolket att resa altare och fira mässa i kyrkans lekmannadel. ${ }^{627}$ Kyrkobyggnadens storlek och utformning bäddar dessutom verkligen för stora skaror av besökare, liksom den stora planen som kyrkogården öster om kyrkan utgjorde. Eftersom klostret fick en central roll för aktörerna i den senmedeltida rikspolitiken och dessutom kunde erbjuda attraktiva avlater för gemene man, samlades stora

\footnotetext{
${ }^{624}$ Anders Fröjmarks avhandling behandlar svenska helgonkulter med anknytning till bl.a. Vadstena, se Mirakler och helgonkult: Linköpings biskopsdöme under senmedeltiden, Univ., Diss. Uppsala, 1992.

625 Regula Salvatoris kap. 15. Lundén bd IV s 27.

${ }^{626}$ Forskning om dessa predikningar se verk av bl.a. Stephan Borgehammar, Alf Härdelin och Roger Andersson.

627 Revelationes Extra. bok 9 kap. 28. Lundén bd IV 1959 s 132.
} 
skaror i Vadstena vid flera tillfällen, inte bara vid den nämnda Katarinafesten 1489. Vad var det då för kyrka som pilgrimerna steg in i? I vilken mån kunde de ta del av samma bildvärld som klosterfolket, och i vilken mån kunde de själva sätta sin prägel på den?

Klostret hade under 1400-talet utvecklats till en betydande vallfartsort, känd även i utlandet. Människor vallfärdade till klostret i hopp om heliga Birgittas bistånd i nöd, eller kanske ännu oftare som tack för bönhörelse. Både inför Birgittas helgonförklaring på slutet av 1300-talet och i arbetet med dottern Katarinas helgonprocess hundra år senare, gjordes omfattande undersökningar för att med vittnesmål påvisa dessa båda kvinnors förmåga att hela och hjälpa de som vände sig till dem i bön. Dessa mirakelsammanställningar var avgörande dokumentation för att påvisa deras helighet. Miraklernas sanningshalt måste intygas av trovärdiga vittnen. Mirakelberättelserna ger emellertid en del information om vad folk faktiskt gjorde när de kom till Vadstena klosterkyrka, och ibland också vad de lämnade som tackgåvor i kyrkan. Den vanligaste gåvan var vaxljus till kyrkan. Man skänkte också föremål som anspelade på det inträffade undret, vilka placerades vid det altare eller helgonskrin vars helgon hade åkallats och bönhört. I mirakelberättelserna om heliga Birgitta nämns bland annat en votivgåva i form av ett barn av vax, som tack för att ett spädbarn från det närbelägna Fornåsa socken överlevt. ${ }^{628}$ När man hundra år senare samlade in mirakler inför Katarinas helgonprocess nämns både vax- och silvergåvor i form av ett par ögon, några huvuden, bröst, en hand, ett par män, en kvinna, en nunna och en häst. Vid Katarinas grav lämnades även bevisen på tillfrisknande respektive frisläppande i form av ett par käppar och en fotboja. ${ }^{629}$ Det finns också "ljusbrickor" av sten och lera som använts för oljelampor vid de olika altarna, på samma sätt som man idag tänder små värmeljus samlade på ställningar vid olika altaren i kyrkorna. ${ }^{60}$ Vid de olika helgonaltarna fanns det således både oljelampor och/eller dyra vaxljus som brann och votivgåvor som prydde platsen, som bevis på helgonets förmåga att hjälpa de fromma.

De många votivgåvorna från pilgrimerna bidrog till kyrkans visuella gestaltning, inte minst för den avgränsade del av kyrkan som lekfolket kunde röra sig i. Inom denna stora och centralt placerade del av kyrkan fanns en med tiden ökande mängd kapell och altaren, instiftade av rika personer. En del av dessa privata altarstiftelser kunde själva vara föremål för vallfart. De altaren som enligt mirakelberättelserna och avlatsbreven fick mest uppmärksamhet av pilgrimerna var jungfru Marias och hennes moders, S Anna. Men i Vadstena var det nog trots allt platserna med birgittinsk anknytning som attraherade flest besökare: Birgitta, Katarina och magister Petrus. Dessa tre gravar och/eller altaren låg också i lekfolkets del av kyrkan och var av naturliga skäl inte påbjudna av heliga Birgitta, utan skapade av hennes efterföljare.

${ }^{628}$ SDHK 10989.

${ }^{629}$ Lundén 1950.

${ }^{630}$ Brickorna finns i klostermuseets trossbod, pall $\mathrm{nr}$ 587, SHM 21172. Länk till bild SHM: http://mis.historiska.se/mis/sok/resultat_foremal.asp?invnr=21172\&samlomr=0\&sort=ASC \&orderby=lokal_\&qtype=f\&search=1\&sm=0_3 (nedladdningsdatum den 19 augusti 2019). 
Den redan flera gånger nämnda skrinläggningsfesten för heliga Birgittas dotter Katarina 1489 var ett unikt pilgrimstillfälle i Vadstena, som attraherade mängder med folk. Klosterbrodern Nils Ragvaldsson berättar som sagt hur man städat, ändrat om i och pyntat kyrkan inför festen, vilket ger oss viss information hur den såg ut vid den tiden, och vad lekfolket kan ha sett. ${ }^{631}$ Han skildrar även hur man arrangerade processioner med klosterfolket och tillresta dignitärer. De allra flesta som var där denna dag var emellertid inte klosterfolk eller kyrkliga dignitärer, utan det lekfolk som står i fokus för detta kapitel. Broder Nils berättar att "hela kyrkogården [var då] full med folk, mer än man kan föreställa sig, hela kyrkogårdsmuren var fullsatt med människor och på alla hustaken närmast kyrkogården satt fullt med folk”. ${ }^{632}$

Festligheterna varade $\mathrm{i}$ tre dagar, 1-3 augusti. Den första augusti var sedan långt tidigare ett årligen återkommande tillfälle då många människor samlades $\mathrm{i}$ Vadstena. Klostret hade sedan 1378 ett särskilt avlatsprivilegium knutet till firandet av "Petri fäng/kedjor", dvs. Petrus ad Vincula-festen, vilken inföll den första augusti. ${ }^{633}$ Genom att fira skrinläggningsfesten i anslutning till detta kunde man räkna med stor uppslutning, vilket också blev fallet. Broder Nils skriver nämligen att ”... allmogen var talrik på alla sidor, icke desto mindre var kyrkan så full som möjligt var. Och det var mycket märkligt och i synnerhet Guds förtjänst att i en så stor och betydande folkskara ingen blev nedtrampad eller trängd..." ${ }^{634}$ För att se till att luftväxlingen i kyrkan var god i sommarvärmen hade man till och med lyft bort en del av fönsterglasen på södra sidan. ${ }^{635}$

\section{Det birgittinska i kyrkorummet}

\section{Helgonskrinen och Birgittabilderna}

Även om heliga Birgitta ville att människorna skulle samlas kring jungfru Marias altare var det Birgittas eget altare som kom att stå i centrum för pilgrimernas vallfart till Vadstena. Som konstaterades i kapitel 1 framgår det av gravkartorna i den Palmskiöldska samlingen (UUB) att det stora Birgittaaltaret var placerat i den östra delen av kyrkan, ungefär mitt i den östligaste mittravén. (Bild 2, 3, 5.) Däremot finns det inga tydliga upplysningar om var heliga Birgittas relikskrin var uppställt under klostertiden. ${ }^{636}$ Det märkliga är att det varken finns spår av skrinets placering eller bevarade uttalanden om var i kyrkan detta viktiga föremål förvarades. Vid kung

\footnotetext{
631 Skildringen ingår i lektionariet KB A 3, översatt och kommenterad av Fritz \& Elfving 2004. Festen nämns även i Vadstenadiariet, DV 884, men mindre utförligt.

${ }^{632}$ Fritz och Elfving 2004 s 51.

633 Se Hallqvist, Katarina, Birgittinsk vägledning. Yta och djup i predikningar för Petri kedjors fest, Otryckt masteruppsats i praktisk teologi, Lunds universitet 2019, s 14 ff, även Höijer 1905 s 98 tar upp festens betydelse.

634 Fritz \& Elfving 2004 s 55-57.

635 Fritz \& Elfving 2004 s 55.

${ }^{636}$ De båda bevarade Birgittaskulpturernas uppställning under klostertiden är inte heller kända.
} 
Karl Knutssons (Bonde) besök 1448 ställdes det upp i högkoret för att välkomna den nye kungen, men inget sägs om varifrån det hämtades fram. ${ }^{637}$ Inte ens i samband med Katarinafesten framgår varifrån man bar fram det.

För en pilgrim var det betydelsefullt att kunna närma sig själva relikskrinet. Helst skulle man egentligen kunna krypa under, genom eller runt det, och ännu hellre, beröra det. I exempelvis både Uppsala- och Nidarosdomen kunde man defilera nära förbi S Eriks respektive S Olofs skrin genom att de var placerade bakom kyrkornas högaltare, men i Vadstena var det omöjligt att göra så på grund av det okonventionella arrangemanget längst i väster, med högkoret i kombination med brödrakoret. Det relikskrin som avses är det silverskrin som var i bruk från 1412 till klosterstängningen 1595, varefter det försvann. ${ }^{638}$ Förutom silverskrinet fanns det ett par andra centrala birgittinska föremål vars placering i kyrkorummet är okänd: Birgittaskulpturen, transportskrinet. Frågan är, var i kyrkan fanns dessa viktiga föremål?

Bild 2 visar den Palmskiöldska gravkartan från sent 1600-tal. Där är en gravsten inritad för heliga Birgittas släktingar, markerad som nr 26 i högkorets norra del. Det är således inte heliga Birgitta själv som avses, vilket dock gravkartan kan antyda. ${ }^{639}$ Det finns goda skäl att misstänka att detta inte heller var platsen för silverskrinet under medeltiden. Andreas Lindblom har framfört idén att silverskrinet under klostrets sista tid var placerat hängande på framsidan av det 1521 invigda nya högaltarskåpet. ${ }^{640}$ Den idag fragmentariskt bevarade predellan till detta högaltarskåp var för visso väldigt stor, men arrangemanget förefaller inte helt lyckat. En naturlig följdfråga blir också var skrinet befann sig före 1521 års, av Lindblom föreslagna, arrangemang? Om skrinet stod i högkoret kunde det bara ses på håll och pilgrimerna kunde definitivt inte gå runt det. Det skulle inte heller vara synligt för nunnorna utan att de öppnade sina insynsskydd på läktaren.

En rimligare placering av helgonskrinet, än den av Lindblom föreslagna, är i närheten av Birgittaaltaret. Det skulle göra att pilgrimerna både kunde komma nära skrinet och på traditionellt pilgrimsmanér cirkulera runt det, precis som Kristina från Gärdslätt gjorde 1470. En tidigare oprövad idé när det gäller placeringen av heliga Birgittas silverskrin, som berörts kort ovan, skulle kunna vara i förbindelse med Marialäktaren. ${ }^{641}$ Man kan då föreställa sig en upphöjd placering bakom Birgittaaltaret, och mellan detta och Marialäktaren. Ett sådant arrangemang skulle hamna inom synhåll från nunneläktaren och vara möjlig att defilera förbi. Pilgrimerna skulle då kunna gå under relikskrinet, på samma sätt som man kan göra med exempelvis Heliga tre konungars skrin i Kölnerdômen, och samtidigt gå runt Birgittaaltaret och passera under jungfru Marias altare. Skrinet skulle även vara väl synligt

637 DV 593.

638 Silverskrinet listas överst i inventarieförteckningen 1595 men värderas inte i vikt.

639 Bennett \& Gustavsson 1985 nr 168.

${ }^{640}$ Lindblom 1965 s 29-30, 32.

${ }^{641}$ Utrymmet under Marialäktaren och bakom Birgittaaltaret är ett område med väldigt få spår av medeltida aktivitet. Det borde ha varit ett "hett" område med tanke på närheten till både Mariaaltaret och Birgittaaltaret. Gravkartorna från 1600-talet lämnar det nästintill tomt. Idag upptas det av den stora orgeln. 


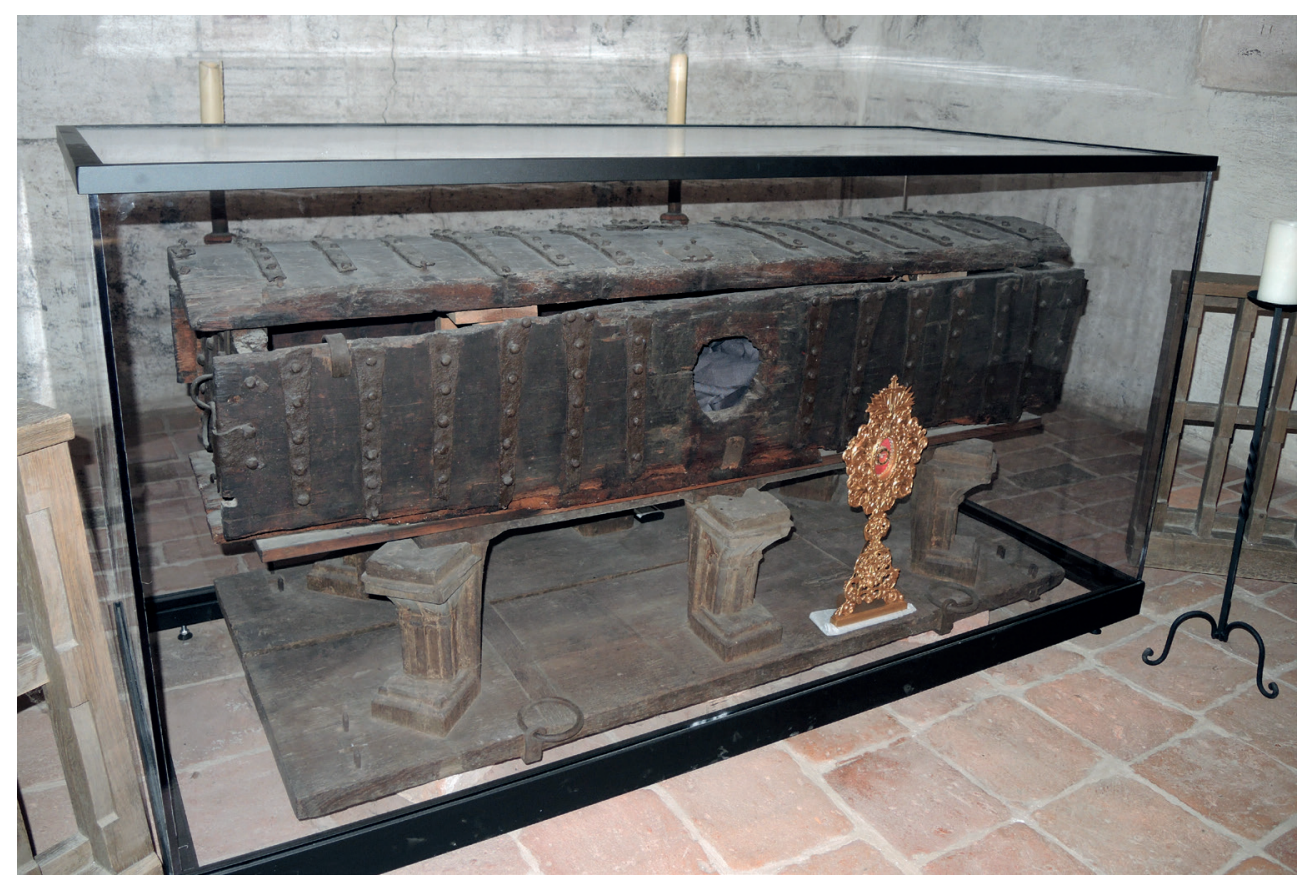

Bild 63. Träkistan som heliga Birgittas kvarlevor fraktades ifrån Italien till Sverige 1373-74. Kistan står numera i klostermuseet. Foto förf.

för både nunnorna, lekfolket på kyrkgolvet och herrskapet på sin läktare. Heliga Birgitta skulle då själv få en prominent placering nära Mariaaltaret, mellan jungfru Maria och nunnorna. Hon skulle hamna i nunnornas blickfång mot öster och hon skulle så att säga gå före dem mot uppståndelsen, i Marias efterföljd. De enda som i så fall inte kunde se skrinet från sitt kor var bröderna, eftersom nunneläktaren och högaltaret skymde sikten för dem. Däremot kunde de komma riktigt nära skrinet i samband med mässfirandet i Mariakoret.

Det finns ytterligare en intressant kista som skulle kunna ha fungerat som pilgrimernas mål i Vadstena, om det inte var silverskrinet: heliga Birgittas transportkista, dvs. den som hennes kvarlevor fraktades hem i från Italien. (Bild 63.) Den är tänkvärd ur flera aspekter. Helt uppenbart är att kistan har utsatts för slitage, och den har inte bara bevarats, utan även hållits tillgänglig för besökare under långa tider. ${ }^{642} \mathrm{Om}$ den inte hade haft detta slitage kunde man tro att den stått undanställd och bevarad av klostret som ett internt kuriosum. ${ }^{643}$ Kistan är av en italiensk tallart medan underredet är av ek. ${ }^{64}$ Det har gått att lyfta bort kistan från underredet, och underredets järnringar kunde användas för att underlätta bärandet av kistan. Vid undersökningen inför Birgittautställningen 1918 fann man sporer etc. av många olika växter som förekommer i Sverige. Däremot tycks den inte ha förvarats utom-

\footnotetext{
${ }^{642}$ Lindblom et al. 1918 s $105 \mathrm{ff}$. beskriver ingående och avbildar transportkistan.

643 Numera är den utställd i det rum som kallas sanctum sanctorum, intill nunnornas dormitorium i klostermuseet.

${ }^{644}$ Lindblom et al. 1918 s 117.
} 


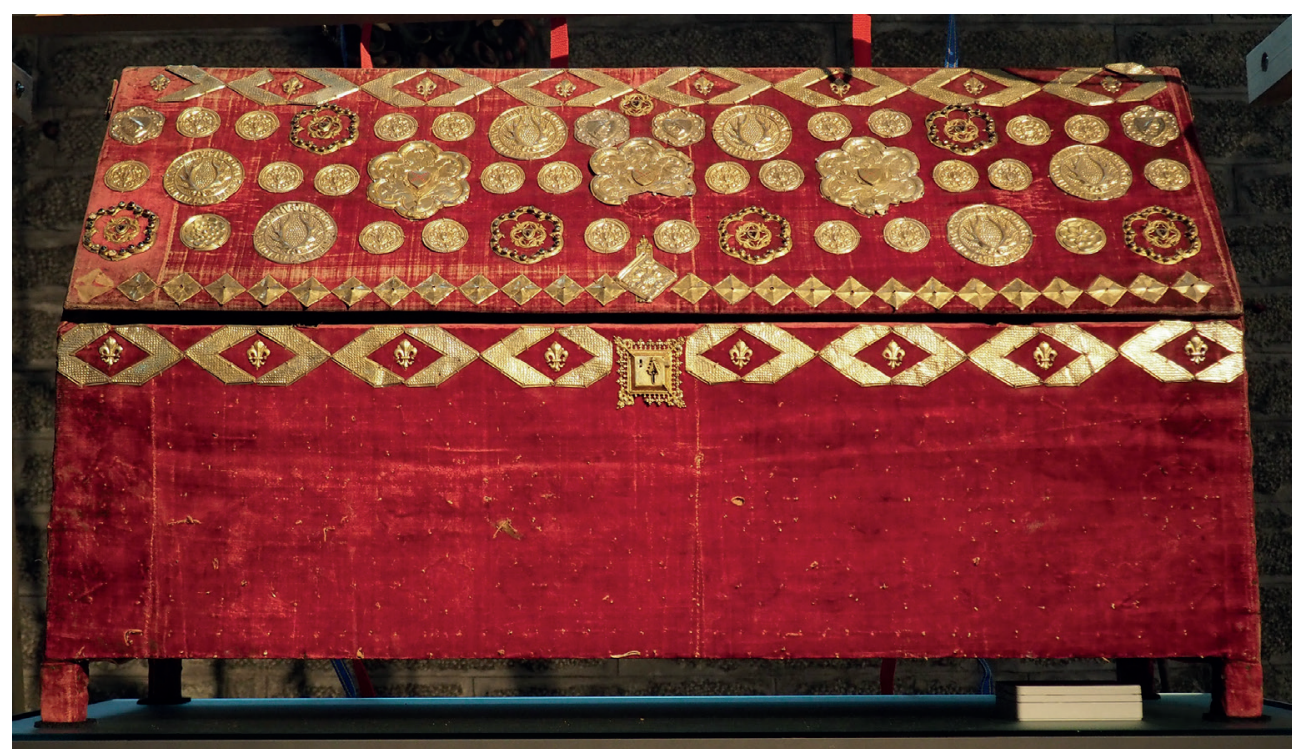

Bild 64. Det röda sammetsklädda relikskrinet som heliga Birgittas kvarlevor vilade i fram till 1412 och dottern Katarina skrinlades i 1489. Skrinet har varit helt översållat med förgyllda silverbleck med olika reliefmotiv, varav många nu saknas. Längd 63,5 cm, höjd $117 \mathrm{~cm}$, djup $39 \mathrm{~cm}$. Foto förf.

hus eller varit jordad, snarare har den förvarats på ett torrt ställe. Man kunde även konstatera att den förmodligen varit exponerad för levande ljus. Man noterade likaså att ena långsidan och kortsidan mörknat mer än det övriga, p.g.a. exponering för bland annat sot. Därav drogs slutsatsen att "kistan, sannolikt under lång tid, stått i ett hörn mot en vägg med de mörkfärgade sidorna utåt” ${ }^{645}$ Enligt en uppgift skulle den ha använts som underrede till ett altare under 1600-1700-talen. ${ }^{646}$ Bruket skulle kunna förklara skillnaden i slitage mellan de olika sidorna, men knappast sotet från ljusen. Frågan är om detta skulle kunna vara ett föremål som man kunde beröra när man nått sitt pilgrimsmål i Vadstena? För de medeltida pilgrimerna var inte berörandet av helgonets kropp det viktiga, och inte heller fick man beröra de påkostade silverskrinen. Storleken på transportkistan, $166 \mathrm{~cm}$ lång, $35 \mathrm{~cm}$ hög och 49-53 cm djup, gör att den går att placera på en ur pilgrimssynpunkt synnerligen passande plats, nämligen i det utrymme som enligt gravkartorna fanns bakom Birgittaaltaret, mellan de båda smalare pelare som flankerade Birgittaaltaret och stödde Marialäktaren ovanför. (Bild 2-5, se vidare nedan.) Det är också tänkbart att det stora runda hålet på skrinets framsida, som tolkats som platsen för ett stort lås, snarare har haft en relikinfattning eller varit ett oculos, dvs. titthål in på ett heligt föremål. ${ }^{647}$ Om silverskrinet hade en annan placering än den nyss föreslagna i Mariakoret, så skulle transportskrinets placering bakom Birgittaaltaret kunna ha varit ett nog så gott mål för pilgrimerna.

\footnotetext{
645 Lindblom et al. 1918 s 116.

${ }^{646}$ Anderson, Iwar, Vadstena gård och kloster, vol 1 Stockholm 1972 s 157 citerar ett av kyrkans 1600-talsinventarier om en "ark av furu" använd som altare.

647 Hålet har en form och storlek som inte tycks svara mot medeltida lås.
} 

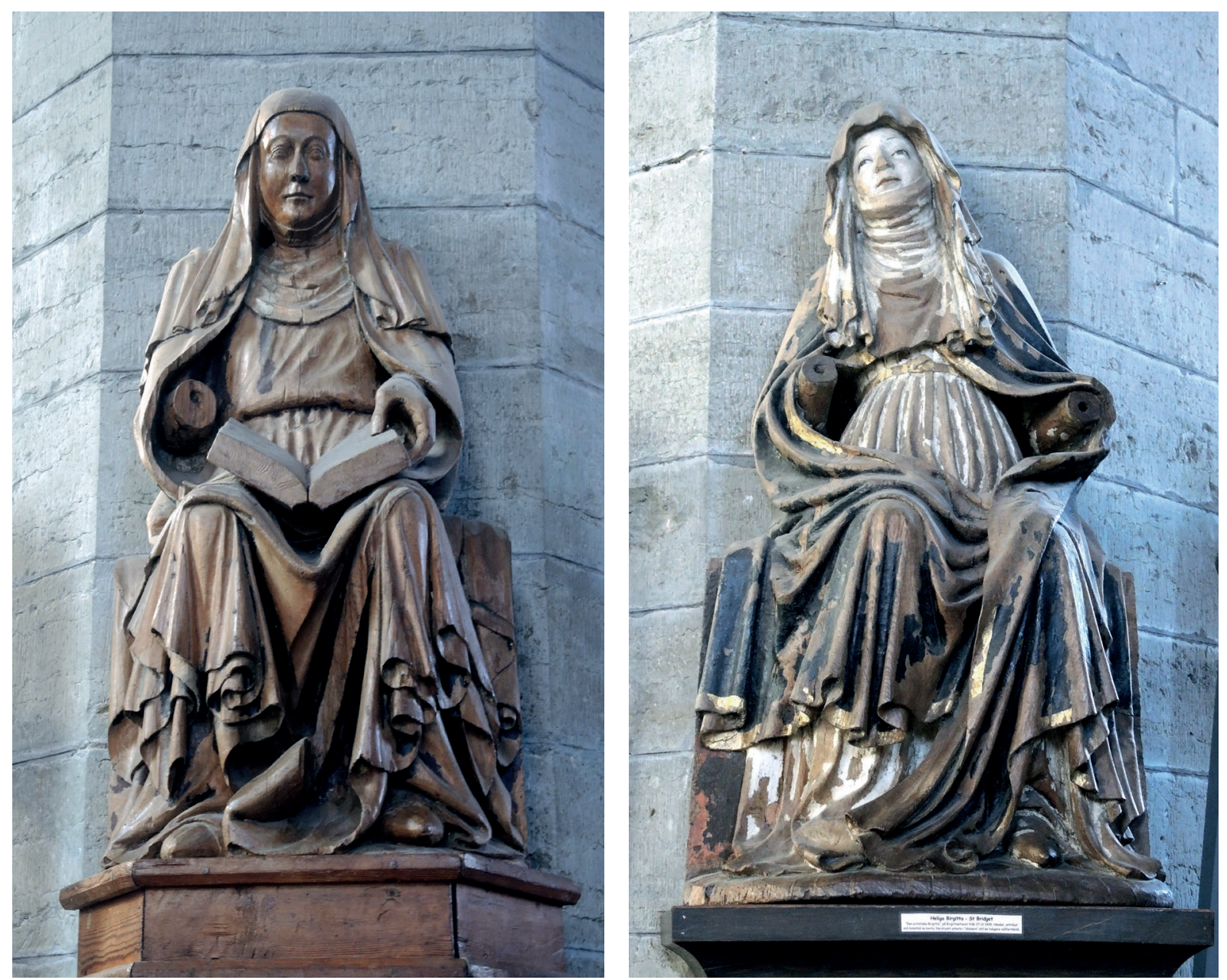

Bild 65. Klosterkyrkan har två skulpturer som föreställer heliga Birgitta. Den "porträttlika" respektive den "extatiska". Den förstnämnda är gjord av al och dateras till sent 1300-tal och den senare är av ek och dateras till ca 1435. Deras ursprungliga placering $i$ klostret/kyrkan är okänd. Foto förf.

Ännu ett skrin har haft en prominent roll i klosterkyrkan: det röda sammetsskrinet. (Bild 64.) Skrinet hyste heliga Birgittas reliker åren 1381-1412, och från 1489 förvarades dottern Katarinas reliker i det. Det innebär att det aldrig varit uppställt i den nuvarande kyrkan med heliga Birgittas reliker i, men däremot med Katarinas. Skrinet visar inga tecken på den typ av slitage på sammeten som kunde förväntas, om det hade varit tillgängligt för pilgrimernas beröring under lång tid. ${ }^{648}$ Möjligen var skrinet placerat synligt men inte berörbart under de exponerade perioderna. Man kan t.ex. tänka sig en upphöjd placering direkt bakom altaret i Katarinakapellet.

De båda bevarade stora Birgittaskulpturerna måste också ha haft viktiga placeringar i klostret. (Bild 65.) Det finns inga uttalanden som pekar ut deras lokalisering överhuvudtaget. Det är rimligt att klostret haft en av bilderna inom klausuren och att den andra var tillgänglig för besökare i kyrkan. En passande bildplacering skulle

${ }^{648}$ Det stora antalet silverbleck som nu saknas har till stor del försvunnit efter medeltiden. 
vara i själva Birgittakapellet. Vid GPR-undersökningen 2018 framkom att det finns ett område på norra sidan av kapellet som inte nyttjats för gravläggningar, vilket skulle kunna antyda en helgonbildsplacering och ge en rimlig förklaring till avsaknaden av gravar just här. Att det fanns en Birgittabild i kyrkan framgår dessutom av ett avlatsbrev som Linköpingsbiskopen Knut Bosson (Natt och Dag) utfärdade i december 1435. ${ }^{649}$ Aron Andersson sätter den s.k. "extatiska" Birgittabilden i samband med detta brev, medan han daterar den "porträttlika" Birgittabilden till slutet av 1300-talet, vilket kunde passa bra ihop med en placering inom klausuren. ${ }^{650}$

\section{Birgittaaltaret}

Eftersom den heliga Birgitta var den som man vallfärdade till i första hand om man begav sig till Vadstena, bör det ha funnits rikligt med votivgåvor och tända ljus vid hennes altare.

På de tidigare diskuterade gravkartorna står Birgittaaltaret mitt i den östligaste mittskeppstravén. På sidorna av altaret går två diagonalställda linjer västerut i riktning mot det östligaste pelarpar som bär upp kyrkans valv. På Kochs gravkarta från tidigt 1800-tal (bild 4) framträder rumsavgränsningen ännu tydligare och man kan även se den efterreformatoriska altarrundeln, samt de båda medeltida altare som står vid det östliga valvbärande pelarparet (markerade med ett + ). Även de båda smäckra pelare som flankerade Birgittaaltaret syns tydligt, liksom ett staket med portöppningar i väst och på ömse sidor om altaret. Det innebär att området under 1600-talet avgränsades som ett femkantigt kor, som dessutom omslöt hertig Magnus gravmonument som skapades 1595. Denna östliga placering, som högaltare med omslutande avgränsning, hade Birgitta-altaret kvar ända tills det revs i samband med 1820-talets omdaningar i kyrkorummet. Birgittaaltarskåpet flyttades då till en placering utmed långhusets vägg och altarskåpet från S Per tog över platsen på församlingens altare. ${ }^{651}$

Det är möjligt att det femsidiga korskranket som syns på 1600-talsplanerna sattes upp först i samband med iordningställandet av hertig Magnus gravmonument på 1590-talet. GPR-undersökningen 2018 stödjer dock tanken att Birgittas altare stått i ett kapell, med någon form av avskärmning, eftersom det framträdde tydliga skillnader i hur olika områden varit använda till gravar. Som nämndes i diskussionen om nunneläktarens plats kan knappast både korskrank och Birgittaaltartavla ha överlevt ett ras som omfattade Mariakoret och/eller nunneläktaren. Det faktum att Birgittaaltarskåpet och de flankerande pelarnas placering förefaller vara konstant både före och efter det stora läktarraset 1580, gör att man kan betvivla att raset överhuvudtaget berörde dessa båda läktare. Som konstaterades i kapitel 1 tyder det snarare på att det var en för tillfället uppbyggd läktare som inte klarade belastningen.

\footnotetext{
649 RA, SDHK 22493, avskrift i UUB C 46 fol. 67v enligt MHUU bd 1 s 297.

650 Andersson 1983 s 37f. Skulpturen mäter $133 \mathrm{~cm}$ på höjden och är $65 \mathrm{~cm}$ bred och $59 \mathrm{~cm}$ djup.

651 Altarskåpet som nu står på högaltaret i väst är alltså från den rivna S Pers kyrka.
} 
allra yttersta sida är båda målningarna mycket fragmentariska, men man kan ana en Kalvariescen. Nästa nivå innebär att man öppnar de två målade pannåerna, vilket skapar fyra pannåer. På de båda mittenpannåerna framställs sex passionsscener. De är i sin tur flankerade av tolv målade mindre scener ur heliga Birgittas liv. När man sedan öppnar skåpets insida visar sig dessutom tolv skulpterade scener som skildrar jungfru Marias liv från bebådelsen till det himmelska upptagandet. De är placerade på flyglarnas insidor. I skåpets mittscen tronar heliga Birgitta under en stor gotisk baldakin, formad nästan som en gigantisk krona över hennes huvud, och hon överlämnar sin klosterregel till de båda knäböjande flankerande kardinalerna. På ömse sidor av henne finns ytterligare tolv scener, placerade $\mathrm{i}$ tre horisontella rader. Det är en komposition där de himmelska härskarorna placerats i översta registret och skärseldens fasor längst ned. Däremellan framställs det världsliga respektive det andliga ståndet, tillsammans med bröder och systrar ur Birgittinorden. Motiven är således kopplade till heliga Birgitta och hennes Himmelska uppenbarelser, men utnyttjar en konventionell komposition. De snidade scenerna med heliga Birgitta i mitten är praktsidan av skåpet, dess guldglänsande insida. För den som besökte klosterkyrkan andra dagar var det utsidans pannåmålningar som presenterades, under fastetiderna bara Kalvariescenen och dess nu bortnötta pendang.

Tillsammans med jungfru Maria är det heliga Birgittas liv och verk som framställs i skåpet. Här vävs de båda kvinnornas liv och uppdrag samman genom att framställas parallellt. Det var jungfru Maria som i stor utsträckning förmedlade budskapet till Birgitta i Uppenbarelserna. Det var också Marias efterföljelse av Kristus som framställdes som idealet och därmed var det likaså hennes perspektiv på frälsningshistorien som förmedlades, genom Birgittas ord. Bilderna på skåpets utsida framhäver dock det mest centrala, Kristi passion. I nästa nivå inramas passionsberättelsen av heliga Birgittas liv, medan den innersta ställer Birgittas roll och budskap i centrum, inramad av jungfru Marias liv. Det blir på sätt och vis ett sammanförande och nästintill jämställande av jungfru Maria och heliga Birgitta för betraktaren. Båda inramar de centrala kompositionerna, men i olika vyer. I de tolv skulpterade scenerna närmast helgonet kan man känna igen scener från de några decennier senare tryckta Uppenbarelserna och överlämnandet av klosterregeln till bröder och systrar (se vidare nedan).

Altarskåpet hade under sina glansdagar en påtaglig prakt genom allt guld som kontrasterade med blått, rött, grönt och vitt. ${ }^{654}$ Dess storlek överglänste sannolikt de andra altarskåpen i klosterkyrkans lekmannadel. Både högaltaret och Birgittaaltaret stod i mittskeppet, nästan i var sin ände av långhuset. De båda altarna skapade två starka poler i rummet. Upp till högaltaret leddes blicken av de tolv apostlaaltarna i plogformation, flankerade av magister Petrus och den saliga Katarinas gravplatser. Birgittaaltarets placering nedanför Mariakoret, öster om nunneläktaren, gjorde den inte mindre synlig. Betraktaren kunde troligen skåda både den heliga jungfruns och heliga Birgittas altaren från en och samma position. Det måste ha funnits många votivgåvor och brinnande ljus vid Birgittaaltaret. Ljusen kunde bidra till ett ljussken

${ }^{654}$ En digital fotorekonstruktion har skapats på föreningen Klosterkyrkans vänners försorg 2012. 
som fångade uppmärksamheten hos den besökare som vände sig mot öster. Det kan inte ha rått någon tvekan om var klosterkyrkans viktigaste altaren fanns, även om Birgittaaltaret var ett tillägg utanför klostergrunderskans egna intentioner. Birgittaaltaret och Mariaaltaret hamnar på sätt och vis i dialog med högkorets altaren, genom placeringen i båda ändarna av salskyrkan. Arrangemanget skapar samtidigt en riktning mot öster, där jungfru Maria kommer först, följd av heliga Birgitta och därefter nunnorna. Som en konkav sköld bakom dem ansluter plogformationen av altarna i högkoret. Det skapar bokstavligen en manlig pol i väst och en kvinnlig i öst, där kvinnorna har tydligt företräde.

Birgittaaltarskåpets bildprogram sammanställdes på 1450-talet, men de specifikt birgittinska bilder som finns där anknyter tydligt till bilder som senare under seklet kom att användas i olika tryckta birgittinska verk, bland annat i den nämnda Lübeckutgåvan av Uppenbarelserna. Kompositionen med den stora, centralt och frontalt, placerade heliga Birgitta, omgiven av nunnor och klosterbröder, finns i flera varianter i både altarskåp, handskrifter och böcker. Det är alltså en komposition som skapades vid mitten av 1400-talet och som man fortsätter att använda femtio år senare. För den lekman som hade besökt klosterkyrkan och på 1490-talet hade råd att skaffa sig ett tryckt exemplar av Uppenbarelserna skapade det ett igenkännande. Även de andra scenerna i skåpets korpus anspelar på Birgittas Uppenbarelser, samtidigt som de placerar sig i den allmänna traditionen av Ytterstadomenframställningar genom sin nämnda tredelade nivåindelning. Scenerna på flyglarna kan dessutom uppfattas som en kontextualisering och normalisering av det Birgittinska in i en mer allmänkyrklig katolsk tradition. En sådan strategi var relevant vid den tid då bildprogrammet skapades, strax efter koncilierna i Konstanz och Basel, eftersom Birgittas Uppenbarelser, hennes renlärighet och orden då ifrågasattes hårt. ${ }^{655}$ Det innebär en konsolidering med den allmänkyrkliga traditionen samtidigt som man profilerade sig birgittinskt. Altarskåpets bildprogram kan således ses som en medveten utåtriktad birgittinsk bildstrategi, en specialkomponerad ikonografi som dessutom stod sig en bit in på 1500-talet, och delvis reproducerades i Gothatrycket och bönboken Jungfru Marie örtagård, daterad 1510 (KB A 12). (Bild 67.)656

\section{Kyrkorummets struktur - Birgittinska poler}

Den flera gånger tidigare nämnda redogörelsen från Katarinafesten 1489 är innehållsrik och ger viss information om hur kyrkans inre var organiserad. Broder Nils berättar t.ex. att Katarinas grav (sedermera hennes altare) låg vid den nordvästligaste pelaren i kyrkan, medan magister Petrus grav var mittemot, vid ett altare nära den sydvästra pelaren. ${ }^{657}$ Detta stämmer också med upplysningarna i diariet. ${ }^{658}$ Tyvärr

655 Se Höjer 1905 kap. VI, Cnattingius, Hans, Studies in the Order of St. Bridget of Sweden. 1, The crisis in the 1420's, Almqvist \& Wiksell, Stockholm, 1963, kap. IV - VII, Nyberg 1965, kap. III.

656 KB ms A 12 folio 171r. Det är en översättning till svenska av systrarnas tidegärd, Cantus sororum.

657 Fritz \& Elfving 2004 s 33.

658 DV 886. 


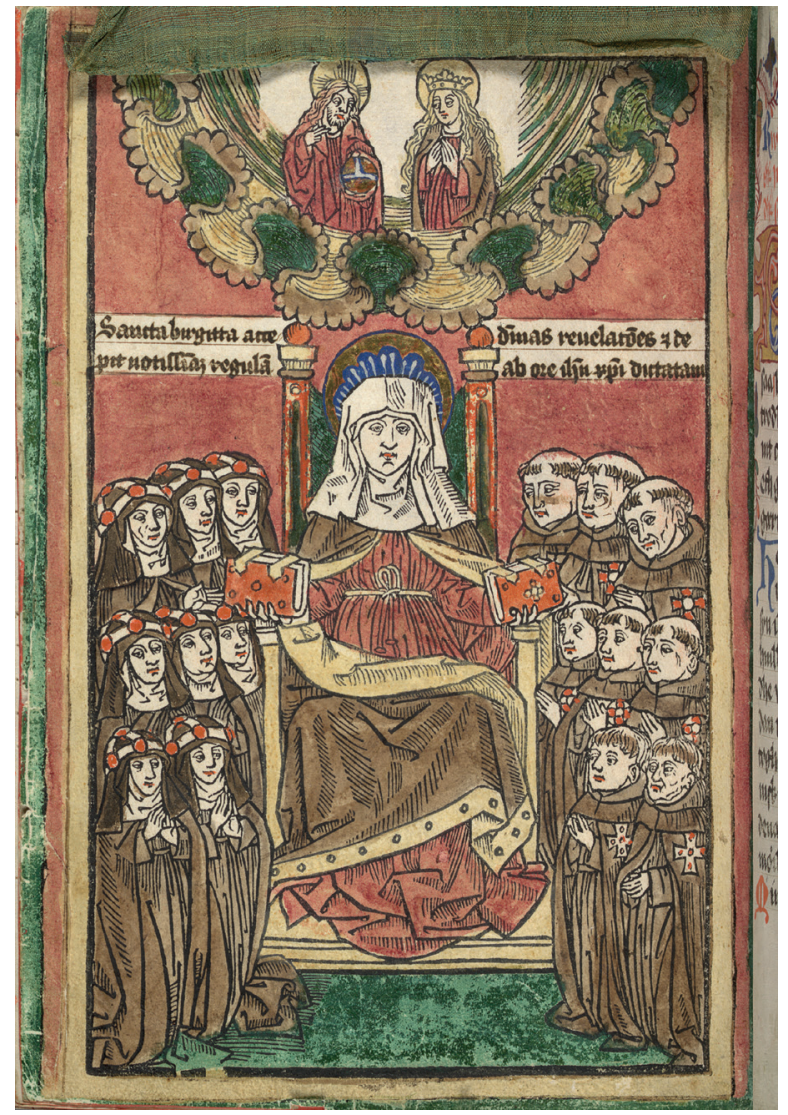

Bild 67. Miniatyren visar heliga Birgitta sittande på en tronstol, flankerad av sina ordenssystrar och bröder. Hon överlämnar klosterregeln till dem, enligt inskriften i bilden. I ett moln över henne ses Kristus och jung fru Maria. Kolorerat träsnitt på papper. Bilden är inklistrad på boksidan och skyddas av en tunn grön silkesgardin som kan fällas undan så att man ser motivet. KB A 12 f. 129 v. (C) Kungliga biblioteket.

har inget av dessa båda viktiga platser lämnat några fysiska spår efter sig i rummet. Genom den rumsligt sett triangelformade placeringen av de tre birgittinskt förknippade individernas altare/gravar skapas en rotationsmöjlighet i kyrkorummet. Birgittas altare kommer besökaren till nästan direkt innanför kyrkportarna. Därifrån leds besökaren vidare in i kyrkan, bort mot högkoret i väster. Effekten blir ett ståtligt arrangemang där högaltaret och de tolv apostlarnas altaren, bakom järngallret, flankeras av magister Petrus och saliga Katarinas respektive gravar och altare intill gallret. (Bild 49.) Genom spridningen i kyrkorummet skapas också en cirkulation för pilgrimerna, ett flöde, så att inte alla stannar upp på samma ställe. Det ambulatorium som man skapade i de gotiska katedralernas kor făr här sin funktionella motsvarighet.

Ytterligare en central plats för pilgrimer att besöka i klosterkyrkan var det nämnda sankta Anna-kor som drottning Filippa grundade 1425 och fem år senare begravdes i. ${ }^{659}$ Koret kallas i diariet även för drottningens kapell och var placerat intill järngallrets norra sida, mellan Katarinas grav/altare och nära ingången till nunnornas konvent, "nådens och ärans port". Kapellet hade därigenom en nästintill klausurgränsöverskridande placering på norra sidan av kyrkan. ${ }^{660}$ Förmodligen var

\footnotetext{
659 DV 406.

${ }^{660}$ DV 238, DV 406. 1653 års gravkarta placerar graven ca 3 alnar från kyrkmuren och ca 8 alnar
} 
kapellet ett tydligt avgränsat rum med väggar av gotiska masverk, utformat för att passa för en drottning. Troligen var det av trä, eftersom några rester av det aldrig påträffats och det inte heller har lämnat några spår i kyrkan ens på de äldsta gravkartorna. I samband med Katarinafesten bekräftar broder Nils berättelse att sådana kapell existerade, eftersom man då tog bort flera "små och stora träbyggnader samt små kor där det inte fanns vigda altaren”. ${ }^{661}$ Filippas kor drabbades sannolikt inte av denna omfattande städinsats, bland annat eftersom det hade ett mässaltare. För att få en idé av hur ett sådant inbyggt kapell kan ha sett ut kan man vända blicken mot de engelska gotiska katedralerna, exempelvis Gloucester och Exeter. Där finns sådana inbyggda rum med gravar på flera platser i kyrkorummet, exempelvis S Gabriels kapell i Exeter. ${ }^{662}$

I drottning Filippas kor fanns inte bara en fin Anna-själv-tredje-skulptur utan också Filippas egen grav med en ännu bevarad gravsten. ${ }^{663}$ Graven bestod av en något upphöjd tumba med den bevarade lockstenen på. ${ }^{664}$ Eftersom drottning Filippa var prinsessa av engelsk börd är det också möjligt att det funnits en begravningsdocka av drottningen i full storlek. ${ }^{665}$ Rester av en trolig sådan förvaras i klostermuseet. Däremot är den i äldre litteratur framförda attribueringen av det nämnda flandriska Kalvariebroderiet som ett gravtäcke för drottning Filippas grav som sagt osannolik. ${ }^{666}$ (Bild 42.) Ett gravtäcke såg helt annorlunda ut och även om Johan III lät göra om gravstenen något så är broderiet för stort för gravstenen. ${ }^{667}$ Ett sådant bruk skulle dessutom ha gett ett karaktäristiskt slitage på tyget från gravstenens hörn, vilket saknas. En placering som vägghängd bonad i kyrkan skulle däremot vara rimlig för broderiet. ${ }^{668}$

Vid ett par tillfällen i klostrets historia nämner diariet att man använt drottning Filippas Anna-kor vid vigningar. Första gången var vid en biskopsvigning 1427, dvs. innan drottningen begravdes där 1430. Diariet nämner koret igen i samband med invigning av två lekbröder 1459. Vid detta tillfälle stod generalkonfessorn på

väster om Nådens och ärans port. GPR-undersökningen 2018 identifierade en anomali på motsvarande plats på ca $0,5-1 \mathrm{~m}$ djup.

661 Fritz \& Elfving 2004 s 31.

662 Foto se https://eph.tuckdb.org/items/5300 (2019-06-15).

663 Bennett \& Gustavsson 1985 nr 167. Stenen omarbetades under Johan III regeringstid. Den avbildas av Eric Dahlberg i Sueciaverket, bild se https://suecia.kb.se/F/U33CDUMRKM8 QLHYS84FKGJJY2B1X7XDXQB2LM2T79YPKBEQ7YP-00268? func=full-set-set\& set_number $=020085 \&$ set_entry=000002\&format=999.

${ }^{664}$ Förstörd mellan 1760-1807 enligt Bennett \& Gustavsson 1985 s 127.

665 Sådana kom i bruk vid det engelska hovet från 1300-talet och kan beskådas i museet i Westminster Cathedral, London. Se även R. P. Howgrave-Graham, The Earlier Royal Funeral Effigies, London 1951.

666 Lindblom hänvisar till en artikel av Agnes Branting 1907, se Lindblom 1965 s 52 . Även Lindblom et al. 1918 s 101 och Branting \& Lindblom del II 1928 s 75 diskuterar proveniensen. Estham 1983 s 109-110 ifrågasätter kopplingen till drottning Filippas grav och daterar broderiet till senare delen av 1400-t.

667 Jämförbara är Holmger Knutssons (SHM 350) och Katarina av Vadstenas gravtäcken (ÖLM 3070).

668 Broderiet mäter $165,5 \times 215 \mathrm{~cm}$. 
högkorets sida av järngallret och de som invigdes stod på andra sidan, dvs. i "drottningens kapell”. ${ }^{669}$ På så vis upprätthöll man klausurgränsen för båda parter. Eftersom man kunde utföra den här typen av ritualer i kapellet kan det inte ha varit så väldigt litet och det måste ha haft genombrutna väggar.

För den pilgrim som ville besöka ytterligare en drottnings grav var det inte många steg från Filippas kapell till det kor som kung Karl Knutsson (Bonde) instiftade och sedan valde till viloplats för sin andra hustru, Katarina Karlsdotter (Gumsehuvud) $1451 .{ }^{670}$ Koret benämns både som Helga Lekamens kor, Vårfrukoret och kungakoret (till skillnad från Filippas "drottningkor"), och förutom vid drottning Katarinas gravsättning nämns det i samband med invigningen av en S Doroteabild 1466. ${ }^{671}$ Graven är markerad på gravkartorna, mellan den norra pelarradens andra och tredje pelare från väst. (Bild 2, 3, 6.) Placeringen av Annakapellet, drottning Filippa och de båda Katarinorna i den nordvästra delen av kyrkan skapar en starkt kvinnodominerad del i det norra sidoskeppet av kyrkorummet. Detta är också i överensstämmelse med att norrsidan var kvinnosidan i de medeltida kyrkorna och i klostersammanhang även nunnornas sida av anläggningen. Den fysiska placeringen i rummet visar här på en idémässigt grundad uppdelning. Huruvida det funnits fler kvinnliga helgonaltaren i närheten av dessa tre kvinnoaltaren är inte klarlagt. ${ }^{672}$

Betraktar man kyrkorummet och dess altaren som helhet framträder vissa tydliga fokusområden, "poler". Dessa var något som heliga Birgitta själv i praktiken skapade genom placeringen av högkoret i väst och Mariaaltaret i öst, båda med upphöjd placering. Något mindre tydliga poler, men ändå med viss betoning i kyrkorummet, är Johannes döparens och S Mikaels altaren utmed norra respektive södra långhusväggarna. Det innebär att de av Birgitta föreskrivna altarna omger lekfolkets område i de fyra väderstrecken. Man kan också betrakta arrangemanget av klosteraltarna som helhet såsom riktat mot öster och jungfru Marias altare. Det innebär att ärkeängeln Mikael och Johannes döparen, tillsammans med Kristi första lärjungaskara, apostlarna, vänder sig till jungfru Maria. I likhet med birgittinerna är de Kristusefterföljare i jungfru Marias fotspår.

En annan polaritet ryms bland lekfolkets altaren i golvnivå där Birgittaaltaret utgör den östra polen och Katarina av Vadstena och magister Petrus tillsammans formar den västra, trots att han inte hade tillägnats ett eget altare. (Bild 68.) Som nämndes ovan skapar de tre centrala birgittinska gestalterna en spetsig trekant i rummet, och de omsluts av klosteraltarna innanför klausuren. Heliga Birgittas altare står där först i ledet som Mariaföljare, med sin placering långt åt öster och nära Mariaaltaret. Birgittaaltarets fysiska placering i kyrkorummet är i linje med Birgittas vilja till efterföljelse. Heliga Birgitta både pekar mot jungfru Maria och följer henne, helt i enlighet med Uppenbarelserna. Katarina och Petrus är sedan de första att följa i Birgittas fotspår, och gör så även genom sina placeringar i kyrkorummet.

\footnotetext{
669 DV 379, DV 698.

670 DV 610.

${ }^{671}$ DV 614, Lindblom 1965 s 239.

67217 av de totalt 52 omnämnda altarna/prebendena i lekfolkets del av kyrkan har kvinnotema.
} 


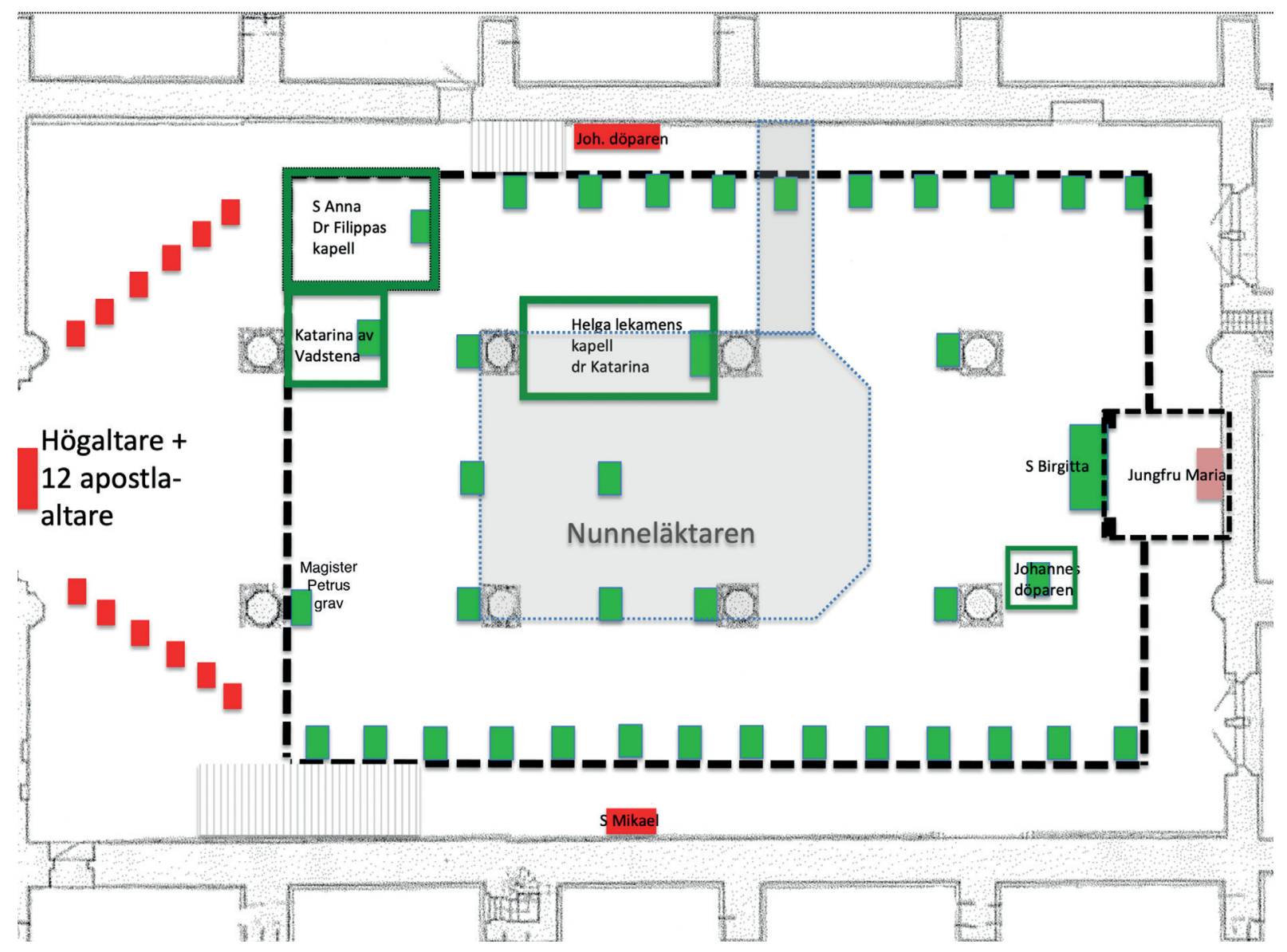

Bild 68. Planen visar hur altaren och vissa kapell $i$ klosterkyrkan kan ha varit placerade. De röda altarna är föreskrivna $i$ klosterregeln. De gröna är ej föreskrivna i klosterregeln. (C) förf.

I lekfolkets del av kyrkan utgör även drottning Filippas Annakapell i nordväst en betydelsefull plats, och det fanns åtminstone ytterligare ett Annaaltare, men placerat på den södra sidan av kyrkan. ${ }^{673}$ Det innebär att det fanns ett Annaaltare på vardera nord- och sydsidan. Även här skapas alltså en slags polaritet, kanhända mindre medvetet formad än placeringen av klostrets och de birgittinska gestalternas egna altaren. Troligen fanns det södra Annaaltaret i närheten av Sturevapnet på södra sidoläktaren. Detta Annaaltare instiftades nämligen av riksrådet Algot Magnusson (Sture) $1428 .{ }^{674}$ För flertalet lekmannaaltaren saknas emellertid tillräckligt med upplysningar för att kunna placera dem mer exakt i kyrkorummet. Placeringen av gravarna kan ge en viss vägledning i den mån som de begravda personerna kan förknippas med altarstiftelser, men lakunerna är många.

\footnotetext{
673 Lindblom 1965 s 237.

674 Ibid.
} 
Med stöd av reduktionsprotokollet 1540 kan man ana att ett par viktiga altaren för lekfolket var Marie smärtors- och Helga lekamensaltarna, eftersom de var till synes rika och beskattades hårt av silverreduktionen. ${ }^{675}$ Eftersom det var kung Karl Knutsson (Bonde) som 1451 grundade Helga lekamensaltaret, och året efter begravde sin hustru där, har vi redan lokaliserat koret till den norra sidan. Marie smärtors altare går inte att lokalisera. Reduktionsprotokollet ger också information om vissa av de altaren som fanns i kyrkan 1540, även om listan inte kan ses som en komplett altarförteckning. Antalet då beskattade altaren var tjugosex, varav sju hörde till klosterklausurens område, av notarien betecknade in claustro. Trots att sex av altarna i protokollet inte anges med placering inom eller utom klausuren finns det anledning att tro att de hörde till lekfolkets del, eftersom det bland annat rör sig om det så kallade biskopskoret och Joan Arnessons kor. I lekfolkets del av kyrkan (in templo) var det flera helgonaltaren som beskattades: S Sigfrid, S Martin, S Nikolaus, S Barbara, S Göran, S Erik, S Maria Magdalena och S Rochus. Det är värt att notera att lekfolkets stora Birgittaaltare inte beskattades alls 1540. Ytterligare helgon är knutna till altarna i kyrkan, men beskattades inte heller vid detta tillfälle. I olika dokument nämns Johannes ante portam latinam, S Erasmus, Marie besökelse, S Andreas, S Katarina av Alexandria, S Ursula, S Hieronymus, S Jakob d.ä., S Olof, S Sebastian samt S Laurentius och S Franciskus. ${ }^{676}$ Det blir sammanlagt trettiotvå lekmannaaltaren, plus de tjugotre som är kända från klausuren, alltså femtiofem dokumenterade altaren i klosterkyrkan. ${ }^{677}$

De trettiotvå altarstiftelser som nämns i källorna kan jämföras med de bevarade tjugofem helgonbilderna, men listan stämmer inte helt överens med de bevarade föremålen. Till de dokumenterade men nu förlorade bilderna hör bland annat Katarina av Vadstena, S Olof, S Sebastian, S Dorotea, S Barbara, en hängande Mariabild och Marie smärtor. $\AA$ andra sidan visar Martins bild från den gamla sakristian att det bland annat funnits ett altarskåp med passionsscener på dörrarna, en vägghängd tavla med en skyddsmantelmadonna och några stora stående skulpturer. (Bild 9.) I en kyrka av Vadstenas dignitet kunde man också förväntat sig att finna altaren och helgonbilder för exempelvis de resandes skyddshelgon $\mathrm{S}$ Kristoffer, S Henrik, S Ingrid av Skänninge och fler ur den populära senmedeltida svenska helgonskaran. ${ }^{678}$ De få som nämns ur den nordiska skaran är S Sigfrid, S Erik och S Olof. ${ }^{679}$

Hur det såg ut vid lekmannaaltarna var i grund och botten ägarnas ensak. Man kan utgå från att det på eller vid respektive altare fanns någon form av visuella referenser till den instiftande/ägande familjen, exempelvis i form av vapenbilder, liksom helgonbilder för de aktuella helgonen. De målade vapenbilderna på sidoläktarna har

\footnotetext{
675 Källström 1939 s 48-49.

676 Lindblom 1965 s 234-241.

677 Ytterligare altaren kan läggas till listan om man beaktar de bevarade skulpturerna.

678 S Ansgar, S Botvid, S David, S Eskil, S Elin, S Knut, S Ragnhild.

${ }^{679}$ Eriksaltaret och Sigfridsaltaret beskattades 1540, Källström 1939 s 284, grundades 1428 av Nils Gustavsson (Rossviksätten), Lindblom 1965 s 234. Olofsaltaret grundades 1435 av Katarina Erengisledotter (Hammerstaätten), Lindblom 1965 s 235.
} 
förmodligen varit placerade så att de anslöt till de olika familjernas altarstiftelser och deras gravplatser. (Bild 6.) I 1400-talsbilder som skildrar kyrkointeriörer kan man se att textilier användes flitigt för att avgränsa koren från omgivningen och att det även kunde finnas avskilda områden inom ett kor, som en liten privat bönekammare för den som ägde altarstiftelsen. I exempelvis Brysselhandskriften ms 9092, en bönbok från 1400-talets mitt, ses Filip den gode titta fram från en liten baldakinliknande bönekammare av blått tyg översållat av gyllene symboler för hans orden, Det gyllene skinnet. ${ }^{600}$ Hela kapellet inhägnas av stormönstrad röd gulddekorerad textil som fästs på pelarna runtomkring. Vid altarets båda kortsidor hänger gröna sidogardiner, "silkesvingar", ned från tunna stänger och på golvet ligger mattor, i detta fall dekorerade med kungens vapen och färger. Altaret är naturligtvis täckt av vit linneduk och pryds även av ett rött antependium och ett altarbrun. På altaret finns en förgylld altartavla. Prästen är klädd i blå mässhake och den assisterande diakonen bär en röd dalmatika. Bakom dem står kören och en grupp ur kungens uppvaktning. I bönekammaren finns det dessutom ett litet altare som täcks av samma tyg som det större altaret, samt en andaktsbild. Naturligtvis såg det inte ut så vid varje lekmannaaltare i Vadstena, men det kan ge en inblick i hur man kunde sätta sin prägel på sin altarstiftelse. Några av de vapenbärande textilier som knyts till klosterkyrkan kan möjligen ha använts i en dylik privat kontext. Man kan också fundera på i vilken mån som de många gravstenarna var bemålade. ${ }^{681}$ En intressant fråga i detta sammanhang är också i vilken grad man under medeltiden använde sina vapenfärger för att markera tillhörigheten. Man skulle kunna tänka sig att exempelvis Karl Knutsson (Bonde) hade textilier som gick i blått och gult vid Helga lekamenskapellet och att familjen Thott använde rött och grönt vid sitt Laurentiusaltare, men denna fråga får lämnas öppen för vidare forskning. ${ }^{682}$

\section{Avlater knutna till klostret och dess bilder}

Innan vi går in djupare på frågan om de många lekmannaaltarnas placering kan man konstatera att det är svårt att tala om medeltida pilgrimer utan att beröra avlatsväsendet. ${ }^{63}$ Möjligheten att få avlat, dvs. reducerad botgöring för begångna synder, var ett viktigt incitament för att bege sig till ett pilgrimsmål. Handeln med avlater var omfattande under senmedeltiden. Det berättas till och med om så kallade "avlatskrämare" som reste runt under slutet av 1400-talet, och vid ett par tillfällen besökte sådana försäljare även kyrkan i Vadstena. Mitt i kyrkorna reste de ett rött kors,

680 Han grundade orden Det gyllene skinnet/La toison d'or.

681 Eftersom de medeltida gravstenarna i kyrkan är utförda i lågrelief skulle färgläggning i skårorna tydliggöra motiven, på samma sätt som på runstenar.

682 Se t.ex. Hablot, Laurent "Revêtir l'armoire. Les vêtements héraldique au moyen âge, mythes et réalités", Espacio, tiempo y forma, serie VII · Historia del arte no 6 2018, Hablot, Laurent "Manuel d'héraldique et d'emblématique médiévale" Tours 2019.

683 Bakgrund och förklaring av avlatssystemet ges t.ex. i Dr Nicolaus Paulus Indulgences as a social factor in the middle ages, Paderborn 1922, s 13-19. Se även Fröjmark, Anders "Den missförstådda avlaten”, Religionsdidaktiska studier red. Torsten Löfstedt, Linnaeus University Press, Växjö, 2015 s 75-87. 
omgivet av fanor med påvens vapen. Vid korset satt försäljaren och hans kassör. ${ }^{684}$ Hur det gick med försäljningen i detta fall är inte känt, men med tanke på alla de avlater som redan var knutna till platsen och som inte var förknippade med pengar, kanske det inte var bästa affärsläget.

För Vadstena kloster gällde som konstaterats vissa särskilda och gynnsamma avlatsprivilegier. Avlaterna knutna till Vadstena kloster daterar sig tillbaka till tiden för grundandet och fortsätter fram till 1517. Några av dem riktar sig specifikt till klosterfolket, men det stora flertalet riktar sig till lekfolket. Syftet med avlaterna var att stimulera lekfolket till syndaånger och fromt beteende, genom att i utbyte utlova vissa lättnader i den förväntade skärselden. Därför handlar avlatsbreven om just andaktsövningar och böner av olika slag, vilket konstaterades redan i kapitel 2. De flesta avlater gällde en standardkvot på 40 dagar, men det var flera Vadstenaavlater som gällde för 100 dagar. Några av utsträckte sig till och med till flera års avlat. Av de äldsta avlatsbreven framkommer exempelvis att man kunde vallfärda till Vadstena istället för till Rom både Birgittas skrinläggningsår 1393 och året efter, $1394,{ }^{685}$ och erhålla samma avlater som i Rom, vilket ju var praktiskt för nordborna. Elva ytterligare avlatsbrev talar i generella formuleringar om att besöka Vadstena kloster, medan sex brev är lite mer utförliga om vilken typ av andaktsövningar som skall utföras för att erhålla avlaten. ${ }^{686}$ Några av avlatsbreven nämner specifika platser och/eller bilder i kyrkan, exempelvis Birgittaaltaret, ${ }^{687}$ en viss Birgittabild, ${ }^{68}$ en Anna-bild, ${ }^{69}$ Anna-kapellet, ${ }^{690}$ jungfru Marie altare, ${ }^{691}$ en Doroteabild eller en Mariabild ${ }^{692}$ och borgmästare Erengisles altare. ${ }^{693}$ Några handlar också om andakter som ska utföras på kyrkogården, för de dödas själars skull. ${ }^{694}$ Vissa avlater utlovas oavsett tidpunkt, medan några gäller för vissa specifika festdagar. Förutom böner och fromhetsövningar så nämns att man skall närvara vid relikvisning, ${ }^{695}$ lyssna till predikan, ${ }^{696}$ höra mässan eller utföra fysiskt arbete åt klostret. ${ }^{697}$ Lägger man ihop de här uppräknade avlaterna som kunde erhållas i klostret, motsvarar antalet dagar drygt tolv år. Dessutom kunde sådana populära rika avlater adderas som var förknippade med vissa enskilda bilder, och som inte hade med klostret att göra, exem-

\footnotetext{
684 Silfverstolpe 1895 s 45-46.

685 SDHK 14199, 14392. Se även Hildebrand, Hans, Sveriges historia från äldsta tid till våra dagar, del 2, Sveriges medeltid, skedet 1350-1521, Linnström, Stockholm 1877, s 160.

686 SDHK 17258, 17974, 19064, 19440, 28576, 29062.

687 SDKH 14041.

688 SDHK 22493.

689 SDHK 19064.

690 SDHK 21298.

691 SDKH 24705.

692 SDHK 28576.

693 SDHK 24705.

694 SDHK 17911, 29062.

695 SDHK 19440.

696 SDHK 15635.

697 SDHK 19440, 30112.
} 
pelvis Veronica/Sancta facies, Gregoriusmässan och den apokalyptiska madonnan, de båda senare med 14000 respektive 11000 års avlat. Kombinationen av klostrets och de enskilda bildernas avlater innebar klart förbättrade utsikter inför skärseldens fasor, för både den bedjande själv och de eventuella andra personer som var föremål för förbönerna. I ett nyfunnet fragment från klostret sägs till och med att det inte finns någon som är så klok att han kan räkna ut hur mycket avlat som man faktiskt kan få genom alla de avlater som då var knutna till klostret. ${ }^{698}$

\section{Pilgrimsmål och begravningsplats - men inte församlingskyrka}

Klosterkyrkan i Vadstena var inte en församlingskyrka, en sådan fanns redan i Vadstena - S Per. Lokalförsamlingen hade ett eget prästerskap, men det hände att dess präster var altarpräster vid något av lekmannaaltarna i klosterkyrkan eller upptogs som bröder i klostret. ${ }^{699}$ Klosterkyrkan hade en annan status och klosterinvånarna ansågs besitta en "specialkompetens" eftersom de ägnade sina liv åt bön. Därigenom fick de en särskilt viktig roll som förebedjare för dem som var utanför klostret. Denna böneuppgift var lika viktig som avlatssystemet. Man kan se det som en försäkringsfråga för det hinsides livet. Att som lekman anlita klosterfolket för att få förböner lästa för sin egen eller närståendes själar innebar att vända sig till verkliga "specialister". Därför var det attraktivt att göra donationer till klostret med böner/ mässor i utbyte. Man kunde givetvis skänka pengar till en vanlig sockenkyrka, eller grunda altarstiftelser där och få sockenprästen som förebedjare, men det ansågs ännu bättre att ha ett helt klosters invånare som förebedjare. Ju fler som bad för samma sak, desto bättre förväntat resultat.

Heliga Birgitta räknade med möjligheten att en del människor skulle vilja begravas i klosterkyrkan, men hon tillät inte att gravhällarna skulle kunna utgöra någon snubbelrisk genom att resa sig från golvytan. Släta golv och gravstenar skulle det vara. ${ }^{700}$ Detta påbud följdes under klostertiden eftersom de medeltida gravstenarna i kyrkan generellt sett utförts i lågrelief. ${ }^{701}$ Vem som helst blev inte heller begravd i klosterkyrkan. Det var främst klosterfolket och klostrets gynnare som begravdes där. ${ }^{702}$ Av gravkartorna framgår att det finns vissa kluster av gravar av olika typer/ status. Finaste områdena att bli begravd på var nära Mariakoret i öster och nära högaltaret i väster. Flera lekbröder och leksystrar fick sina gravar i den östra delen av kyrkan, medan vi kan konstatera att flera medlemmar av Birgittas släkt hade sina

\footnotetext{
${ }^{698}$ Hallqvist, Katarina, Birgittinsk vägledning. Yta och djup i predikningar för Petri kedjors fest, Otryckt masteruppsats i praktisk teologi, Lunds universitet 2019, s 84-85.

699 Nämns i DV 561, DV1016.

700 Revelationes Extra. kap. 38. Lundén bd IV 1959 s 142.

701 Kända undantag från regeln är Katarina av Vadstenas samt drottning Filippas och drottning Katarinas upphöjda gravtumbor.

702 Se Bennet \& Gustavsson 1985, katalog över gravstenarna i kyrkan 1985.
} 
gravar i området kring pelaren vid Katarinaaltaret. (Bild 2.) Det visar sig även att vissa adelssläkter ligger mer sammanhållet.

I några fall går det att koppla ihop altare och gravplats, som när det gäller väpnaren Jösse/Jens Eriksson (Lykke) och hans altare till Johannes döparen, placerade sydväst om Birgittaaltaret. Eftersom Johannes döparens bild finns bevarad i två olika versioner i kyrkan är det troligt att den ena av dem prytt detta altare. Det är möjligt att man kan lokalisera även S Olofsaltaret i anslutning till den grav för Hammerstaättens Katarina Erengisledotter (1435), som var placerad i det norra sidoskeppets östligaste travé. ${ }^{703}$ En av de få Snakenborgsgravarna har likaså legat i det norra sidoskeppet, mellan första och andra travén från öster, och ett altare till Johannes ante portam latinam instiftades av Birgitta Henriksdotter (Snakenborg) och Ture Jönsson (Svarte Skåning) 1481. ${ }^{704}$ Ett av Anna-prebendena var som sagt placerat i det södra sidoskeppet, liksom det kombinerade Laurentius \& Franciskusprebendet, men oklart exakt var. Det sistnämnda instiftades 1432 av en medlem av familjen Porse, Birgitta Magnusdotter. Hennes och makens (Erik Stensson Bielke, d. 1410) vapensköldar var avbildade på den södra läktargången, troligen mellan den fjärde och femte valvbågen från väster. (Bild 6.) Det är tänkbart att koret till S Laurentius och Franciskus var placerat i närheten. På den norra sidans läktare fanns, förutom Hammerstaättens vapen, även familjerna Öra, Styke och Bonde representerade med vapensköldar, men det går inte att knyta dem dokumentariskt till något av de kända altarna. Däremot fanns det gravar för släkterna Styke och Bonde i närheten av dessa läktarmålningar.

Det går således att se en viss koppling mellan lekmannaaltarna, läktarmålningarna och gravarna, men sambandet går inte alltid att påvisa på grund av källäget. Exempelvis är drotsen Bo Jonssons (Grip) tidigare nämnda grav- och altarplacering problematisk. Han begravdes redan 1386 och dessförinnan instiftade han Helga korsaltaret. När han dog fanns bara en träkyrka på platsen och det är inte känt exakt var denna kyrka stod i förhållande till den senare fullbordade klosterkyrkan. En gravsättning i närheten av Helgakorsaltaret hade varit rimlig, men hans grav flyttades senare till en position vid den sydöstra ingången till stenkyrkan enligt gravkartorna. (Bild 2, 3.) En "normal" placering av Helga korsaltaret vore centralt i den västra delen av kyrkan, någonstans mitt framför högaltaret. Inför Katarinafesten 1489 berättas att man murade upp Helga korsaltaret på nytt, men oklart var. ${ }^{705}$ Eftersom klosterkyrkan har färdigställts långt efter drotsens död och graven flyttats, går det inte att avgöra den primära placeringen. Kyrkans inre har tyvärr aldrig grävts ut systematiskt. ${ }^{706}$

Efter klosterinvigningen 1430 övertog Vadstena klosterkyrka under 1400-talet raskt rollen som den svenska adelns viktigaste begravningskyrka. ${ }^{707} \mathrm{Genom}$ att bli begravd i klosterkyrkan fanns man nära dem som bad för ens själ. Hörde man till

\footnotetext{
703 Lindblom 1965 s 235. Bennett \& Gustavsson 1985 nr 53, s 62-63.

704 Lindblom 1965 s 235.

705 Fritz \& Elfving 2004 s 31.

706 Den nämnda georadarundersökning som genomfördes 2018 omfattade inte den västra och södra delen av kyrkan, se Rossi 2019.

707 Klosterinvigningen 1430 nämns i DV 412. Högaltaret invigdes först 1442, DV 529.
} 
de rika som blev begravda i kyrkan, så fungerade också gravstenar och vapensköldar som påminnelser om de utlovade förbönerna. Samtidigt var vapenbilder och gravstenar i lekfolkets del av kyrkan statusmarkörer gentemot besökarna. Klosterkyrkan var en plats där adeln visade upp sig inför andra, för varandra och Gud genom gravstenar, läktarmålningar, glasmålningar och altarstiftelser. ${ }^{708}$ De tidigare nämnda möjligheterna att som stiftare påtala sin roll genom altarnas utrustning, med broderade vapensköldar på textilierna, i valet av färger eller med hjälp av målade vapen på altarbilderna och gravstenarna, var en viktig del av den visuella kommunikationen och bidrog påtagligt till kyrkorummets gestaltning. ${ }^{709}$ Lekfolkets kyrka måste ha präglats starkt av alla dessa altaren och inbyggda kapell. Det över $1800 \mathrm{~m}^{2}$ stora kyrkorummet blev därigenom uppdelat i en mängd mindre rum och enheter som var omslutna av brödernas läktaromgångar och högaltaret, med nunneläktaren över lekfolkets huvuden.

Adelns inverkan på kyrkorummets utformning i Vadstena klosterkyrka var således stor. För pilgrimer av enklare härkomst innebar kyrkobesöket ett möte med en bildvärld som trumpetade ut makt, prakt och djup fromhet. Deras egna sockenkyrkor kunde kanske visa upp ett par extra helgonaltare förutom Mariaaltaret och det helgon som kyrkan var invigt till. Här i Vadstena fanns det altaren i överflöd på ett sätt som till och med överträffade de flesta domkyrkor. Den totala utstyrseln för dessa många kor och kapell måste ha varit anslående, och inneburit en hisnande upplevelse för besökaren att vandra mellan. Här presenterades dessutom alla de fromhetstrender som var på modet, genom kultbilder som exempelvis Rosenkransmadonna, Marie smärtors altare och framställningar av Sancta facies, Kristi sår, Gregoriusmässan och Smärtomannen.

Merparten av besökarna brydde sig troligen inte så mycket om adelns privata altaren, om det nu inte var ett helgonaltare som förknippades med en speciellt eftertraktad egenskap, som exempelvis pesthelgonet $\mathrm{S}$ Rochus eller de sjöfarandes och resandes skyddshelgon S Nikolaus. De altare eller gravar man kom till Vadstena för att besöka var främst heliga Birgittas, Katarinas och magister Petrus' samt, att döma av de bevarade diplomen, även jungfru Maria. De flesta helgonen kunde man uppsöka i de flesta större kyrkor och katedraler, även om ovanligt många av dem var representerade just i Vadstena klosterkyrka. Det man från klostrets sida så att säga kunde locka med var det specifikt birgittinska. Detta kunde ingen annan kyrka erbjuda, men genom de många tillagda lekmannaaltarna i kyrkan presenterades det hela i en allmänkyrklig kontext. En för klostret positiv effekt blir att den i början av 1400-talet hårt ifrågasatta birgittinorden och heliga Birgittas Uppenbarelser successivt inlemmas i den normala/bredare kyrkliga kontexten. Dess särprägel blir mindre iögonfallande när den presenteras tillsammans med allt det andra "normala", samtidigt som den birgittinska särarten ändå ges utrymme att glänsa och attrahera fler besökare.

708 Glasmålningar var inte tillåtna enligt klosterregeln men enligt Silfverstolpe 1898 s 15, 82 nämns sådana i ett brev från 1421, se även Anderson 1991 s 66.

709 En jämförelse till Vadstena, och inblick i resonemangen kring heraldiken, ger Katarina Lemmels brev i Schleif, \& Schier 2009. 


\section{En pilgrimstur i kyrkan 1470}

De flesta mirakelberättelser om heliga Birgittas och saliga Katarinas underverk nämner endast kort att den helade personen beger sig till klosterkyrkan i Vadstena. När det gäller Kristina från Gärdslätts by (nära Boxholm), som 1470 besökte kyrkan för att få bot mot sin förmodade förgiftning, ges lite mer information om hur hon rörde sig på platsen. ${ }^{710}$ Hon kom till kyrkan vid högmässotid, vilket i klostret var redan på morgonen. ${ }^{711}$ Mirakelberättelsen uppger att hon gick "bort till” Katarinas grav, vilket stämmer med lokaliseringen i den västra delen av lekfolkets kyrka, längst bort från ingångarna. Vid Katarinas grav kastade hon sig på marken och bad, men var så trött efter den ansträngande färden att hon somnade. (Före 1489 hade man inte ännu något Katarinaaltare, men det sedermera anlagda altaret var på samma plats som graven.) Under sömnen uppenbarade sig fru Katarina för Kristina och uppmanade henne att inte bara gå till Birgittaaltaret, utan också att sedan gå runt det på sina bara knän. Förmodligen hade Kristina sovit en god stund, för när hon avverkat två besvärliga varv på knä runt Birgittaaltaret, uppmanade kyrkväktaren alla att lämna kyrkan för dagen. Det hade blivit eftermiddag. Man kan konstatera att det uppenbarligen var ett visst avstånd mellan Katarinas grav och Birgittas altare, vilket stämmer med planen. De var i var sin ände av lekfolkets kyrkorum. Vi får också veta att det gick att ta sig runt Birgittaaltaret på knä. Uppmaningen att knävandra runt altaret får också en större betydelse om Birgittas eget skrin också fanns där, i anslutning till altaret.

Genom att följa tätt i fotspåren av den stackars Kristina från Gärdslätt kan vi konstatera att när hon gick in genom den sydöstra porten passerade hon de avlatsutfästelser som klostret gav besökarna och som fortfarande finns inristade i en stentavla utanför porten. ${ }^{712}$ Hon var emellertid inte på besök för att få avlat för det hinsides utan för att bli helad i det jordiska livet. Efter att ha tagit sig genom kyrkporten måste hon ha passerat utanför Birgittakapellet, på vägen bort mot Katarinas grav i väster. Den fortsatta vandringen gick längs med södra läktargången, förbi dess målade vapenbilder och ett antal lekmannaaltaren. Där fanns som nämnts tidigare, bland annat ett altare till S Anna och ett för S Laurentius och S Franciskus. När hon gick där kunde hon också se S Mikaelsaltaret uppe på den södra läktargången, nära de tyska adelsmännen Murach och von Parsbergs röd- och vitmålade vapensköldar på läktargångens vitputsade murar. På golvet kunde hon se gravstenarna för adelsfamiljerna Natt och Dag, Snakenborg, Bielke, Krummedige och Porse m.fl. De var sannolikt bemålade så att vapensköldarna och inskrifterna framträdde tydligare i den grunda reliefen. På sin väg bort till Katarinas grav passerade hon även i närheten av magister Petrus Olofssons grav. Den låg vid den sydvästra pelaren, intill järngallret. Vid de tre bärande pelare som hon just passerat stod också helgon-

\footnotetext{
710 Berättelsen återges i Vita Katherine, övers. Tryggve Lundén 1981 s 77-78.

711 Uhrberg 2017 s 269, Rajamaa 1992 s 93-95.

712 I sv. övers: Så talar Guds son: Jag har förestavat klosterregeln och skänkt samma avlat som finns att få $i$ kyrkan Sankt Petri in Vincoli i Rom... för utförlig text se Anderson 1991 s 45.
} 
altaren. Altarna var vända mot öster, ställda mot pelarna, och inramade av draperier på sidorna ("silkesvingar") så att man inte såg vad de rymde för altare förrän man kom över på deras västra sida. Under den knappt två travéer långa nunneläktaren stod ytterligare altare, några av dem var troligen avgränsade som små gotiska träkapell. Vid något av de många altarna kanske en präst läste mässan. Framme vid Katarinas grav, vid den nordvästra pelaren, kunde hon klappa den nötta pelarbasen och sätta sig ned på golvet. Hon kunde höra hur brödernas mörka röster ljöd från deras kor bakom högaltaret i väst, följda av nunnornas ljusa röster som intonerades från nunneläktaren $\mathrm{i}$ öster, direkt efter att brödernas tidebön hade slutat. Kanske vaggades hon till sömns av nunnornas recitationer och hymner, trots att det var en av de kortare tidebönerna, non. Efter nonen var det en liturgisk paus i kyrkan fram till vespern vid tretiden på eftermiddagen.

När Kristina vaknade följde hon instruktionen i drömmen och tog sig ännu en gång tvärs genom kyrkorummet, nu till det stora Birgittaaltaret i öster. När hon reste sig upp såg hon först drottning Filippas inhägnade Annakapell på norra sidan, väldigt nära Katarinas grav. I golvet där Kristina gick låg bland annat en gravsten med Finstaättens röda vapensköld. ${ }^{713}$ Två pelare österut från saliga Katarinas grav stod ytterligare ett av kyrkans större kapell, med gravplats för en drottning, Katarina Karlsdotter (Gumsehuvud). Gravkoret var det Kristi lekamenskapell som hennes make, kung Karl Knutsson (Bonde), instiftade 1451. I likhet med drottning Filippas Annakapell avgränsades troligen även detta kor mot resten av kyrkan genom väggar av gotiskt masverk. Av gravkartorna kan man ana att drottning Katarinas tumba var placerad mitt emot korets pelaraltare. ${ }^{714} \mathrm{Om}$ Kristina från Gärdslätt vred huvudet lätt mot vänster så kunde hon kanske se Johannes döparens altare uppe på den norra läktargången, och längs med läktarens vitputsade tegelsidor fanns en rad målade vapensköldar från familjerna Öra, Styke, Bonde och Hammerstaätten. De var målade i rött, blått, vitt, grönt och guld på den vita putsen. (Bild 6.) På golvet i närheten fanns gravstenar för en del medlemmar av dessa familjer. Om Kristina sneddade mot sydost genom kyrkorummet passerade hon troligen Helga korsaltaret, och kanske även S Sigfridsaltaret strax intill. ${ }^{715}$ När Kristina passerat under nunneläktaren var hon framme, mitt framför Birgittaaltaret och dess stora altarskåp. Golvet under läktaren pryddes av färgglada gravstenar från ytterligare frälsesläkter (Sture, Sparre, Lejonansikte, Bielke, Nipertz, van Vitzen m.fl.). Det var fint att begravas i detta område eftersom det var nära både Maria- och Birgittaaltaret.

Området kring Birgittaaltaret var sannolikt utformat som ett eget kapell, men större än de båda kungliga kapell som Kristina just passerat under sin vandring. Vid den norra sidan i Birgittakapellet stod förmodligen en av de stora Birgitta-

713 Enligt UUB Palmskiöld 294 gravkarta plats för Katarina Knutsdotter, heliga Birgittas barnbarn som var hovdam hos dr Filippa. Enligt diariet (DV 153) begravdes hon i sina släktingars grav. Flera personer ur denna släkt har alltså gravlagts i närheten av Katarinas grav och sedermera kapell.

714 Tumban är inte bevarad men däremot lockstenen.

715 Helgakorsaltaret byggdes om 1489 och Sigfridsaltaret grundades av familjen Trolle 1435, Fritz \& Elfving 2004 s 31, Lindblom 1965 s 234-235. 
skulpturerna, och där hade tacksamma människor lämnat sina gåvor till heliga Birgitta. ${ }^{716}$ Där brann många oljelampor i små skålar av sten. ${ }^{717}$ Framme vid Birgittaaltaret gick Kristina två varv på knä runt det. På både norra och södra sidan fanns det troligen portar i korskranket som möjliggjorde att man kunde gå runt altaret. Hon passerade även några betydligt enklare gravar för klostrets lekfolk bakom altaret. Antagligen fanns det även en Mariabild, placerad bakom Birgittaaltaret, vid den östra muren, rakt under Mariaaltaret. Det var där lekfolket lämnade sina gåvor till den heliga jungfrun. Förmodligen fick Kristina även ta sig förbi fogden Jösse Erikssons (Lykke) Johannes-döparen-kapell på den södra sidan om Birgittakapellet, när hon rundade Birgittaaltaret. Det är tänkbart att även heliga Birgittas transportskrin var uppställt på baksidan av altarskåpet, dvs. mellan de slanka pelarna som bar upp Mariakoret. Kombinationen av helgonaltaret och transportkistan skapade i så fall ett konventionellt pilgrimsmål, lätt att defilera runt tillsammans med altaret. Men, eftersom det inte heller är känt var heliga Birgittas silverrelikskrin var uppställt, är det frestande att ge det antingen en placering bakom Birgittaaltaret, eller upphöjt på Mariakoret. Båda placeringarna är tänkbara och funktionella ur pilgrimssynpunkt. En sådan placering av silverskrinet skulle göra det möjligt för pilgrimerna att defilera under det, på liknande sätt som man kan göra under Heliga tre konungars skrin i Köln. Samtidigt skulle ett sådant arrangemang kunna ge silverskrinet en position som var synlig från långt håll i kyrkorummet och från både nunnornas och herrskapets läktare.

Sannolikt lämnade Kristina kyrkorummet via den norra porten, och då passerade hon S Olofsaltaret vars stiftare Katarina Erengsiledotter (Hammerstaätten) hade sitt röd-gula vapen målat på såväl gravstenen i golvet som på läktarmuren. ${ }^{718}$ Kanske hann Kristina även rikta en bön till de vägfarandes helgon S Nikolaus på vägen ut ur kyrkan, för att komma väl hem efter sin resa. ${ }^{719}$ Utanför porten kunde hon avsluta sitt besök i klosterkyrkan genom att beröra de nötta korshålen i kyrkans yttermurar, innan hon vände söderut och tillbaka mot staden, under sitt mycket mödosamma tillfrisknande.

Det som Kristina från Gärdslätt kunde se under sin vandring i kyrkorummet var således i hög grad präglat av de frälsesläkter som hade sina altarstiftelser och/eller gravar i kyrkan. De kungliga koren och frälsesläkternas altaren basunerade ut både vilka personer som hade förmånen att vila i kyrkan och vilka helgon som dessa helst åberopade. På detta sätt var klosterkyrkan som en normal katedral, full med altare och gravar. Inslaget av inbyggda kapell var kanske mindre representativt i jämförelse med de nordiska domkyrkorna, där kapellen helst placerades utmed långhusets sidoskepp. Lekfolkets yta kringgärdades dessutom både av långsidornas läktargångar,

\footnotetext{
716 Georadarundersökningen 2018 visar att det inte tycks ha varit några gravar i detta avgränsade område, vilket tyder på att området använts till något som försvårade gravsättning där.

717 SHM 21172, länk http://mis.historiska.se/mis/sok/fid.asp?fid=45356.

718 Lindblom 1965 s 235. Det altare i närheten som stiftades till Johannes ante portam latinam fanns inte 1470 eftersom det inte skapades förrän 1481.

719 S Nikolaus altare är känt från kyrkan, men inte dess placering eller vem som instiftade det. Något Kristofferaltare är inte dokumenterat.
} 
de båda koren i öst respektive väst samt nunneläktarens nästintill svävande position över besökarnas huvuden. Visserligen kunde lekfolket röra sig fritt över den stora golvytan inom järngallrets ramar, men det blev ett med tiden allt gyttrigare rum, att döma av den stora utrensning som man gjorde inför skrinläggningsfesten $1489 .{ }^{720}$

\section{Lekfolkets altaren}

Frågan om de många altarnas placering i klosterkyrkan har berörts ovan och av tidigare forskning, men det är för det mesta bara de i regeln föreskrivna klosteraltarna som brukar placeras in på kyrkplanen när detta diskuteras eller rekonstruktionsmodeller görs. Som vi har konstaterat ovan fanns det betydligt fler altaren och kor, liksom även hela kapell, men företrädesvis i lekmannadelen av kyrkan. Några av dem nämndes nyss i samband med Kristina från Gärdslätts besök 1470, men för det mesta är den precisa lokaliseringen i rummet svår eftersom vi saknar tydlig information. Ett exempel på altare som kan lokaliseras ungefärligt är Hammerstaättens S Olofsaltare. Det bör ha funnits i den nordöstra delen av kyrkan, tack vare närheten mellan gravstenen och sidoläktarens målade vapensköld. Placeringen av lekmannaaltarna påverkas av två sammanhängande faktorer, nämligen frågan om var gränsen gick för klausuren och i vilken mån den gränsen avgjordes av var klosterfolket var gravlagda. Om gravplatserna för klosterfolket låg utanför kyrkan innebär det att lekfolket i princip kunde ha tillträde till området under sidoläktarna, vilket nämndes redan i kapitel 1. Då kunde klausurgränsen upprätthållas med hjälp av nivåskillnaden mellan sidoläktare och kyrkgolv. Till viss del kan även frågan om i vilken mån lekmannaaltarna hade placering ad orientem vara vägledande för resonemanget liksom storleken på de bevarade altarbilderna, vilket likaså berördes i i inledningen.

Klosterkyrkorna i Maribo, Mariager och Nådendal har inte till närmelsevis lika många altarskulpturer bevarade som Vadstenakyrkan. Därför finns inte underlag för en storleksjämförelse av dem när man diskuterar lekmannaaltarna för de andra kyrkorna, men för Vadstenas del är det relevant. Det finns ett mindre antal små helgonfigurer bevarade i Vadstenakyrkan som skulle kunna knytas till några av de altaren som är kända genom dokument, t.ex. Maria Magdalena och den mindre Laurentiusfiguren. ${ }^{721}$ För att få en uppfattning om storleken på utrymmet under läktarna kan man jämföra med de delvis bevarade ursprungliga läktarna i Maribo kyrka. ${ }^{722}$ Även om utsträckningen i kyrkorummet och djupet på läktarna inte är det ursprungliga där, så är höjden och utformningen det. Om man tänker sig lekmannaaltaren placerade i arkaderna under läktargångarna, skulle de minsta helgonbilderna kunna ha haft sin placering på dessa altaren. De flesta av de bevarade bilderna och skåpen i Vadstena är dock alldeles för höga för att stå på ett altare under en sådan

\footnotetext{
720 Fritz \& Elfving 2004 s 31.

721 Maria Magdalenabilden förvaras på klostervinden. S Laurentius se http://medeltidbild. historiska.se/medeltidbild/visa/foremal. asp?objektid=920914S9.

722 Bilder från Maribo se Norn 1948 fig. 5, 7, 20, Frederickson 2016 s 40-41, länk till bilder på Maribo domkyrkas hemsida se https://www.maribodomkirke.dk/galleri/ (nedladdad den 19 augusti 2019).
} 
läktargång. De ryms helt enkelt inte där. I Mariager menar man att lekmannakapell har funnits under läktargångarna, men tydliga medeltida utsagor saknas, liksom altarbilder. ${ }^{723}$ Det faktum att det var gravkapell där efter reformationen är tyvärr inget belägg för att det var lekmannakapell där tidigare.

En komplikation med kapell placerade under sidoläktarna är bristen på ljusinsläpp. I Maribo kyrka finns nischer i tegelmurverket, men inte fönster/ljusgluggar. Kyrkmurarna i Vadstena är murade av solid kalksten och har inga som helst spår av murförtagningar, fönster eller annat ljusinsläpp där läktarvalven suttit. Det finns inte heller några notiser om eller avritningar av sådana spår från äldre tider. Fönster i markhöjd på den norra sidan innebär dessutom risk för insyn i nunnornas klausur. En sådan "risklänk" mellan lekmannaaltarnas präster och nunnorna är otänkbar och hänger ihop med frågan om var klausurgränsen gick, och om järngallrets placering.

Heliga Birgitta hade ju tänkt sig ett avgränsande järngaller runtom kyrkans inre, och att bröderna skulle ambulera i de gångar som detta skapade i marknivå längs med nord- och sydväggen. Utrymmet i gångarna skulle vara 4 alnar brett, drygt $2 \mathrm{~m}$. Man följde inte instruktionerna helt. I praktiken murade man istället upp läktargångar och kunde ambulera ovanför golvnivån. Förmodligen hade gångarna ändå det angivna breddmåttet. Det skulle kunna innebära att man inte behövde något avgränsande galler i golvnivå utmed långsidorna av kyrkan, utan att man hade ett räcke längs läktarnas överkant. Att det fanns någon form av räcke uppe på dem framgår av berättelsen om Katarinas skrinläggningsfest 1489, då man prydde räckena med många ljus. ${ }^{724}$ Det är således tänkbart att klausurgränsen upprätthölls genom en differentierad nivå, där bröderna rörde sig uppe på läktarna och lekfolket kunde komma in under sidovalven. Däremot uppstår svårigheten att upprätthålla klausuren om det finns öppningar in till nunnornas klausur från lekmännens altaren under sidoläktarna. Klausurgränsen mellan nunnorna och utomstående var dessutom viktigare och strängare än den som gällde för bröderna i relation till lekfolket. I Vadstena finns det emellertid inget som tyder på att det funnits öppningar i kyrkmurarna. Det innebär dessutom att det borde ha varit väldigt mörkt där, och snabbt blivit ännu mörkare på väggar/tak av sotet från de levande ljusen på altarna.

Det framstår även som tveksamt att stiftarna skulle investera i kapell som ingen kunde se något av, och vars prakt ingen heller kunde uppfatta på grund av dunklet. Visserligen finns det många medeltida konstföremål som inte varit tänkta att ses i första hand av mänskliga ögon, utan vars existensberättigande har mer teologiska orsaker. Däremot var det ovanligt att senmedeltida donatorer undanhöll information om vem och vad man donerat. Att manifestera sin roll/betydelse var angeläget, inte minst i Vadstena klosterkyrka, som övertagit rollen som rikets viktigaste manifestationskyrka för frälset. De målade vapensköldarna på läktarsidorna vittnar om vikten av att synas.

\footnotetext{
723 Krongaard Kristensen 2018 s 102.

724 Fritz \& Elfving 2004 s 16, 33. I Mariager hade man ett skulpterat stenräcke som formade ringkors, se Krongaard Kristensen 2018 s 87, 137.
} 
Det är möjligt att sidoläktarvalven i Vadstena var sammanlänkade på samma sätt som de nu är i Maribo, så att det gick att passera i öst-västlig riktning från det ena valvet till det andra under läktaren, utan att gå ut utanför valven. Med en sådan sammanlänkad öppen arkadgång blir det samtidigt omöjligt att placera altarna $\mathrm{i}$ riktning mot öster under läktarna. Ett östorienterat altararrangemang skulle göra att altarna spärrade passagen mellan valven. Det innebär i sin tur att altarna under valven i så fall måste ha varit riktade mot norr respektive söder, vilket i kapitel 1 konstaterades vore en tydlig avvikelse från det brukliga. ${ }^{725}$ Heliga Birgittas föreskrifter påtalar däremot att att Johannes döparens och ärkeängeln Mikaels altaren skulle placeras så att de mässfirande prästerna var vända mot norr respektive söder. För de andra altarna inom klausuren var riktningen ad orientem outsagd (se ovan kap. 1).

Ytterligare en aspekt till frågan om lekmannakapellens eventuella placering under läktarna hänger samman med klosterfolkets begravningsplats, som likaså berörts tidigare. Om klausuren inte gällde området under läktarna så är det tveksamt om klosterfolket har begravts där. Det skulle ha inneburit att de begravdes utanför klausuren. ${ }^{726}$ I Vadstenabrödernas råd till det 1415 nygrundade klostret Syon Abbey utanför London, rekommenderade de dotterklostret att begrava sitt klosterfolk just på platsen under sidoläktarna. ${ }^{727}$ Utgrävningar i Syon Abbey har visat att de följde Vadstenabrödernas råd noga på den punkten. Där har systrarna fått sina gravar under sidoläktarna utmed norra väggen och bröderna utmed den södra. ${ }^{728}$ Några motsvarande arkeologiska utgrävningar har inte gjorts i Vadstena, och därför finns det inga konkreta belägg för det. Däremot kan man ifrågasätta om Vadstenabröderna skulle rekommendera ett begravningsbruk som de själva inte tillämpade. Möjligen kan den förut nämnda begränsade utgrävningen i södra delen av klosterkyrkan 1922 tyda på att man ovetande var brödernas gravar på spåren. Man fann nämligen enbart mansskelett, lagda i flera lager.

Problemen med att placera lekmannaaltaren i nischerna under läktararkaderna tyder på att altarna aldrig var placerade där, utan att utrymmet under läktargångarna snarare hörde till klausuren. ${ }^{729}$ Som gravplats för klostret gjorde det inget att området var mörkt. Samtidigt var det enkelt att nå gravarna via öppningarna mellan valven. Det hörde till brödernas uppgifter att begrava klosterinvånarna, vilket de kunde göra obehindrat med ett sådant arrangemang. Det skapar inte heller några svårigheter att upprätthålla klausuren ur denna synvinkel, eftersom järngallret fungerade som gräns, troligtvis förankrat i arkadstöden. De privata altarna kunde därmed placeras vid läktarnas murverk. Genom att placera dem i 90 graders vinkel ut från valvstöden skapades rätt riktning på altarna, mot öster. Sådana vinkel-

${ }^{725}$ Kroesen 2010 isht s $14-17$ och presenterat plan/bildmaterial.

726 Många kloster begravde sina medlemmar i klostergården, omgiven av klostergången.

727 Andersson 2011 s 131. Detta talar även för att sidoläktarna fanns med i de tidiga planerna i Vadstena.

${ }^{728}$ Forbes 2013 s 73-92.

729 Den georadarundersökning som gjordes i norra sidogången 2018 ger inget underlag för tolkning av området som gravplats för klostret. 
placerade altararrangemang har varit vanliga under medeltiden. ${ }^{730}$ Lekmannakapellen begränsas därmed inte heller när det gäller höjden på altarnas kultbilder. Även större helgonbilder och altarskåp kan då placeras där. På detta vis kunde man som donator även tydligt visa vilket altare man grundat genom att låta måla sin vapensköld på den murpelare som anslöt till koret/altaret. Sannolikt valde donatorn dessutom sin gravplats i närområdet. För lekmännen som besökte kyrkan innebar de visuella markörerna att det gick att orientera sig mellan de olika altarna, trots deras sedvanliga koravgränsningar. Järngallret kunde dessutom fungera väl för att fästa votivgåvorna vid, vilket sannolikt var fallet med gåvorna vid Katarinas grav på 1470-talet. Den omvittnade bärsärkagång som hertig Magnus utländska musikanter ägnade sig åt 1552 säger tyvärr inget om huruvida de attackerade bilderna befann sig under eller vid läktarna. ${ }^{731}$

\section{Antalet altaren i kyrkan}

Klosterkyrkan är stor och antalet altaren var många, men hur många var de egentligen? Broder Nils Ragvaldsson berättar ju att man inte bara tog bort, utan även byggde om och ändrade på altaren och kapell i samband med Katarinafesten, för att det var för trångt. Man kan tyvärr inte bara addera alla omnämnanden av altarstiftelser eftersom det finns de som fått ny patronus eller ändrats i dedikationen, men varit kvar på samma plats. Antalet altaren har också varierat under årens lopp. Flest instiftades under 1400-talets första hälft, medan det var mindre frekvent med nya stiftelser under seklets senare del. Den italienske handelsmannen Pietro Querini, som besökte Vadstena på 1432, räknade till fyrtiotvå altaren, troligen inklusive klostrets sexton mässaltaren. ${ }^{732}$ Antalet bevarade skulpturer och altarskåp vittnar i sig om drygt femtio altaren ${ }^{733}$ medan Andreas Lindblom kom fram till totalt sextioen altaren. ${ }^{734}$ Antalet dryga femtio stämmer dock inte helt överens med vad som har dokumenterats i skrift. Adderar man alla omnämnanden med bevarade bilder kommer antalet upp i över sjuttio altaren. ${ }^{735}$ Genom att använda all den tillgängliga dokumentationen och föremålen går det kanske att avgöra rimligheten i detta. Lindbloms lista innefattar omnämnandet av totalt sjuttio altaren eller altarprebenden. I Martins skildring av föremålen i sakristian ses tjugofyra kultbilder, varav ett par bör räknas bort eftersom de är från tiden efter reformationen. Av de tjugofyra är sex placerade i ett skåp eller mot ett ryggstycke. I klosterkyrkan och klostermuseet finns numera sammanlagt trettiosju altarskåp

\footnotetext{
730 Kroesen 2010 abb. 12, 98, 100, s 64-71.

731 Lindblom 1965 s 217.

732 Borgehammar, Stephan, "Ett pilgrimsbesök i Vadstena år 1432", Annales Academiae regiae scientiarum Upsaliensis, 2001/2002 (34), s. 27-38, Uppsala 2003.

733 Vissa helgonbilder står numera i skåp som de inte är avsedda för och altarskåpen vilar på predellor från andra, förlorade skåp.

734 Lindblom 1965 s 90-92.

735 Några bilder kan ha tillhört S Pers kyrka.
} 


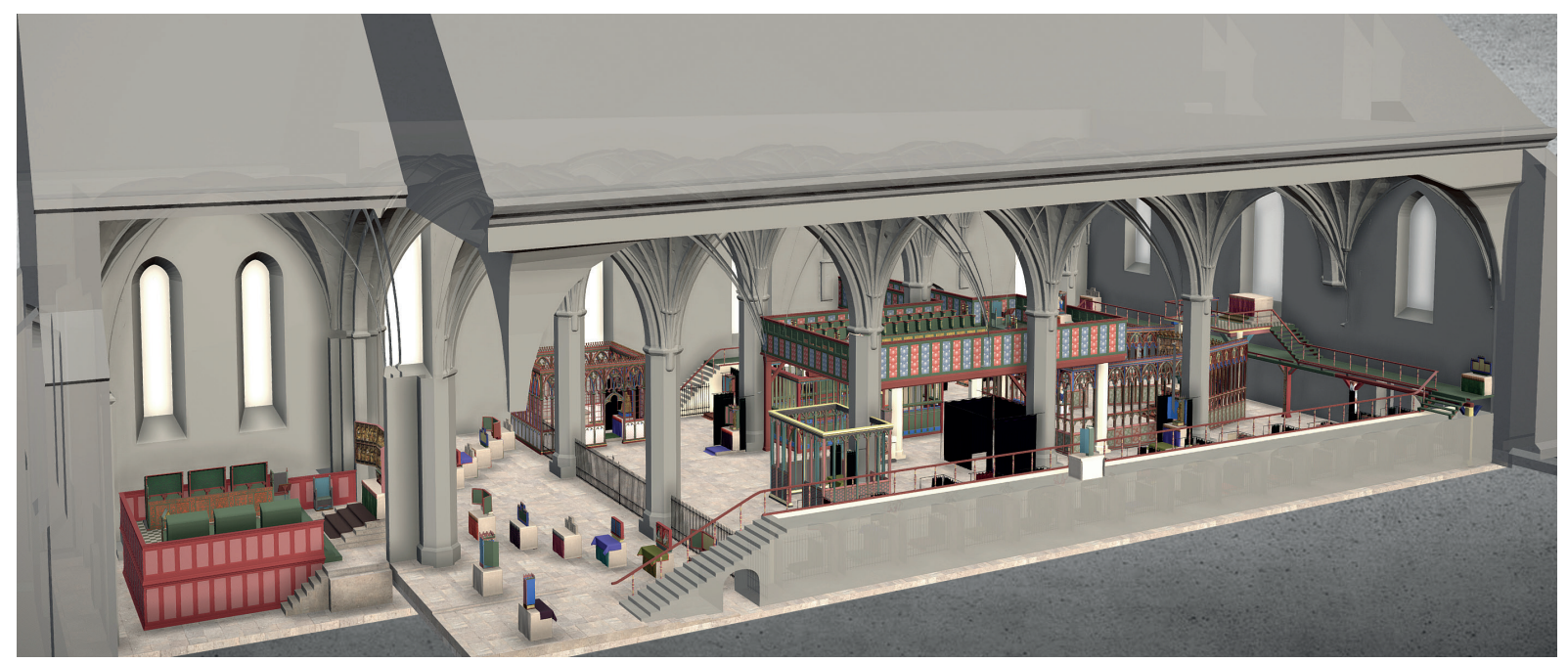

Bild 69. Rekonstruerad översikt av den medeltida kyrkans interiör omkring 1470. (C) förf. och Carolina Ask.

eller helgonbilder. ${ }^{736} \mathrm{Av}$ de nio som idag har någon form av skåp eller är placerade mot ryggstycken är det sex som är sekundärt kombinerade. Det innebär att de sex föremålen skulle kunna härröra från tolv olika altarbilder. En jämförelse av listan över altarstiftelser med reduktionsprotokollet 1540 avslöjar att flera helgon/ altarbilder numera saknas. De namngivna som nu saknas är S Olof, S Erik, Marie smärtor, evangelisten Johannes, S Sebastian, Johannes ante portam latinam, Katarina av Vadstena, S Dorotea, Treenigheten/Nådastol, S Rochus, S Barbara, S Göran, S Martin och antingen S Sigfrid eller S Nikolaus. ${ }^{737}$ För fyra av altarstiftelserna saknas upplysning om dedikationshelgon. Förteckningen har därmed ökat från fyrtiotre till sextioen bevarade bilder, skåp eller delar därav. Det är ett mycket högt antal och högre än exempelvis Uppsala domkyrka, och når den skattning Lindblom gör, men utan att redovisa sina resonemang.

Oavsett om det var femtio, sextio eller sjuttio altare finns det all anledning att fråga sig hur man överhuvudtaget fick plats med alla dessa altaren? Om man utnyttjar kyrkans bärande pelare, nunneläktarens stödpelare, sidoläktarnas valvstöd etc. som placeringspunkter, går det i princip att få in ganska många altaren. (Bild 68,69 .) Enbart genom att placera altarna utmed kyrkans långsidor, i rät vinkel mot läktargångarnas arkadstöd, skapas plats för tio altaren på norra sidan och fjorton på den södra, dvs. tjugofyra potentiella platser. Med ett sådant arrangemang blir det även gott om utrymme kvar kring de åtta pelarna som bär upp kyrkans valv. Vid sex

736 Andreas x 2, Anna x 3, Birgitta x 2, Biskop, Jakob d ä, Johannes döparen x 2, Birgittaskåp, Rosenkrans, Apokalyptisk madonna, Sköna madonnan, Mikael x 2, Laurentius x 2, Påve, Katarina Alexandria, Katarina av Vadstena, krucifix x 3, Maria Magdalena, Madonnan i kapitelsalen, Hieronymus, Smärtoman x 2, Kristus i väntan, S Ursula, Visitatio, stora s.k. madonnaskulpturen i museet, tom triptyk, tom predella. Till detta kommer kalvariegruppen i SHM som förknippas med biskop Bene Korp. Det finns även sex ljusbärande änglar som ej anses ha hört till något altare utan förknippas med Katarinafesten 1489.

737 Det biskopshelgon som finns i kyrkan saknar attribut och är inte identifierat. 
av dessa åtta pelare skulle ytterligare altaren kunna placeras, med riktning mot öster. Det innebär plats för trettio lekmannaaltaren. Det är också tänkbart att de fyra förlorade pelare som identifierades vid GPR-undersökningen 2018 varit förknippade med altare. Det är känt att det fanns altaren även vid de två västligaste valvbärande pelarna, där magister Petrus och Katarina av Vadstena hade sina respektive gravplatser. Summan blir då trettiotvå altaren. Dessutom känner vi till placeringen av Birgittaaltaret och har en någorlunda klar bild av var både drottning Filippas Annakor och Karl Knutssons (Bonde) Helga lekamenskor var placerade. Det senare med förankring vid en av pelarna i den norra raden. Som tidigare nämnts fanns det även ett altare tillägnat Johannes döparen på Birgittaaltarets sydvästra sida, grundat av Jösse Eriksson (Lykke.) Antalet potentiella platser för lekmannaaltaren kommer då upp i trettiofem. Tillsammans med de stipulerade sexton mässaltarna enligt Birgittas instruktioner blir det femtioen altaren. Enligt reduktionsprotokollet från 1540 beskattades ytterligare fem altaren inom klausuren: Birgitta, Kristi, Helga lekamen, Rosenkransen och Marie smärtor, ${ }^{738}$ dvs. ett antal av femtiosex mässaltaren. ${ }^{739}$ Ytterligare en handfull altaren kan beläggas genom omnämnanden, men det är inte säkert att de skulle utöka antalet, eftersom deras placering skulle kunna vara vid någon av de nämnda pelar- eller sidoläktarplatserna. Det förekom som sagt även att altarstiftelser ändrade dedikationshelgon, vilket var fallet med exempelvis Karl Knutssons (Bonde) Helga lekamensaltare. ${ }^{740}$

Med hjälp av gravkartorna kan man dock göra vissa rimliga antaganden om ytterligare några av altarnas placering. Hammerstaättens S Olofsaltare från 1435 har redan nämnts, placerat i närheten av den nordöstra utgången, liksom Jösse Erikssons (Lykke) Johannes döparenaltare (1428) nära Birgittaaltarets södra sida. (Bild 70.) På södra läktaren var ett Sturevapen målat enligt Elias Brenners teckning och det skall ha funnits även ett Annaaltare på södra sidan, instiftat av Algot Magnusson (Sture) 1428. Flera Sturegravar fanns också i den mittskeppstravé som stod närmast väster om Birgittaaltaret. Således har vi ett Annaaltare ungefär mitt på södra sidan eller vid andra pelaren från öster. På södra sidan finns även flera gravar för medlemmar ur släkterna Krummedige och Bielke, placerade mellan första och andra pelaren från väster. Ture Stensson (Bielke) grundade ett altare åt S Erik, S Anna och S Birgitta 1428. Hans båda hustrur kom från de danska släkterna Tjurhuvud respektive Krummedige och deras tre vapensköldar återfanns under 1600-talet på en gravsten i södra sidogångens näst östliga travé. Det är möjligt att altaret var placerat vid den intill liggande pelaren, dvs. nr två från väster i södra raden. Mitt i raden av vapensköldar på södra sidoläktaren ses vapnen för Bielke \& Porse. Birgitta Magnusdotter (Porse till Fållnäs) grundade det redan förut nämnda altaret för S Franciskus och S Laurentius 1432, vilket tidigare hade varit tillägnat jungfru Maria, S Anna och Alla helgon. Birgitta Magnusdotter var gift med Erik Stensson (Bielke). Det är

\footnotetext{
738 Källström 1939 s 48-51.

739 Nunneläktarens andaktsaltare ej inräknat eftersom det inte var ett mässaltare.

740 Övergick från Vårfrualtare till Helga lekamensaltare, men kallades även för Capella regis, dvs. kungakapellet.
} 


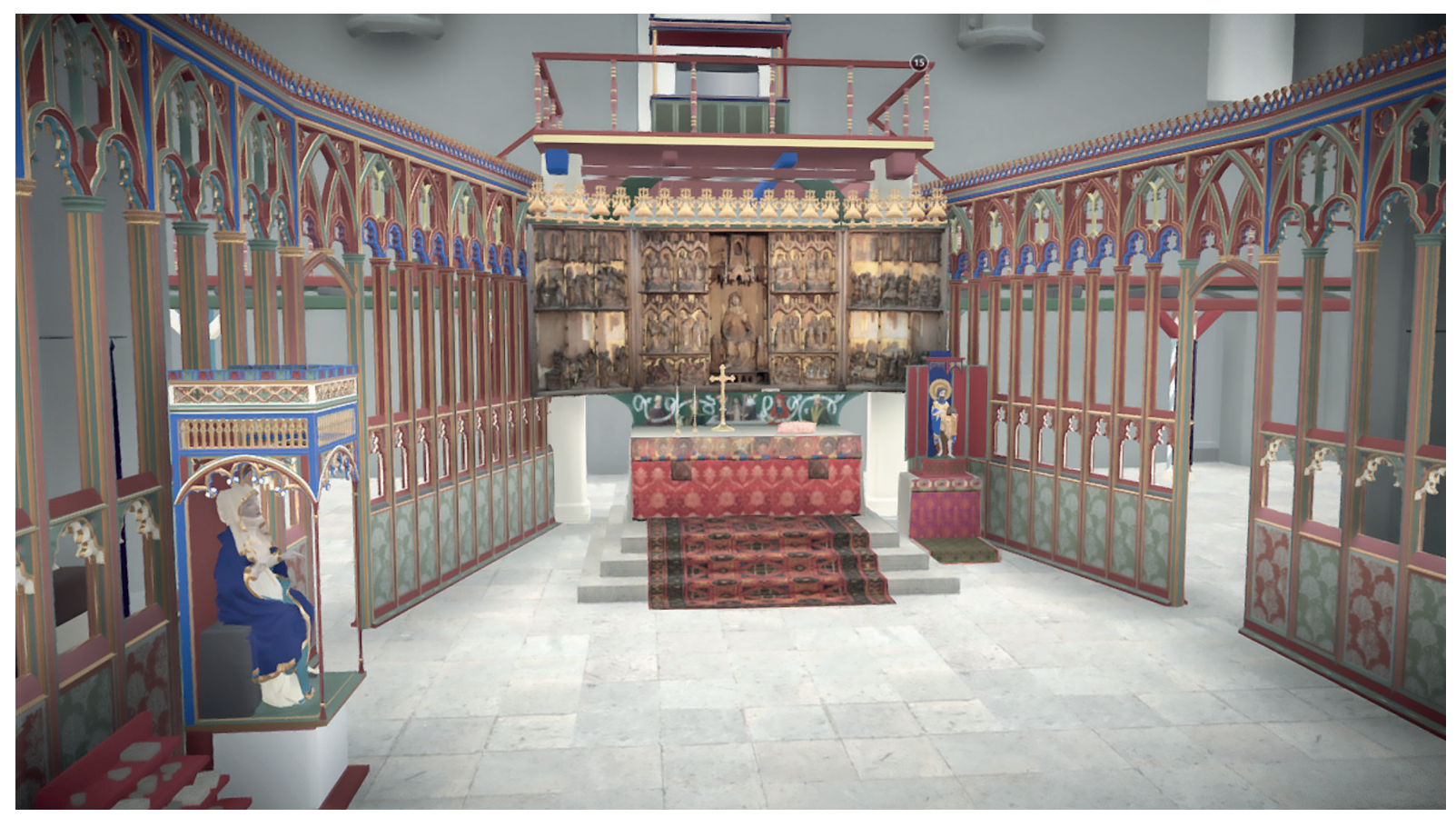

Bild 70. Rekonstruktion av Birgittakapellets utformning ca 1470. Vy mot öster med Mariakoret som reser sig bakom altarskåpet och Jösse Erikssons (Lykke) Johannes döparenaltare på den södra sidan. (C) förf. och Carolina Ask.

troligen deras vapen som syns på Brenners teckning från den södra läktararkaden. (Bild 6.) Det är alltså möjligt att dessa två Bielkeassocierade altaren restes i den sydvästra travén i lekmannakyrkan. I den östra delen av södra sidoskeppet finns även en grav för Jöns Magnusson (Abjörn Nockessons ätt, sparre över fallande blad). Fadern, väpnaren Magnus Jönsson och modern Märta Bengtsdotter (Rödbjälke) skapade en altarstiftelse till S Birgitta $1440 .{ }^{741}$ Graven ligger mellan Birgittaaltaret och den sydöstligaste pelaren, vilket passar bra tillsammans med Birgittadedikationen. Även familjen Natt och Dag har både gravsten och vapenbild på kyrkans södra sida, men några dokument som binder dem till någon altarstiftelse i klosterkyrkan är tyvärr inte kända. På samma sida av kyrkan bör troligen S Laurentiusaltaret och ytterligare en Annastiftelse placeras eftersom deras stiftares vapenbild varit målad på läktargången, nämligen Ingeborg Ivarsdotter (Ivar Nilssons ätt). Själv är hon begravd i Danmark men fadern begravdes i Vadstenakyrkan 1417, i mittskeppets andra travé från öster. ${ }^{742}$ Riksrådet Arvid Trolle (d. 1505) var inblandad i grundandet av två olika altarstiftelser i Vadstena, men är inte begravd där. ${ }^{743}$ Den ena stiftade han tillsammans med svågern Laurens Haraldsson (Ängaätten) till S Jakob och

741 Lindblom 1965 s 235 attribuerar den porträttlika Birgittabilden till denna altarstiftelse, men det finns inget som styrker det.

742 Nr 56 på Kochs gravkarta.

743 Domprosten Erik Trolle begravdes mitt i kyrkan 1459, men han förde inte samma vapenbild, se Bennett \& Gustavsson 1985 s 41. 
S Sebastian, medan den andra var tillägnad S Erasmus. ${ }^{744}$ Den förstnämnda skall ha legat öster om Johannes döparens kor, dvs. det altare som Jösse Eriksson (Lykke) grundade. Det innebär en sannolik placering av S Jakob och S Sebastian i den sydöstligaste travén, nära sydöstra ingången.

För den norra sidan av kyrkan har Hammerstaätten redan nämnts, likaså att det troligen går att placera även altarstiftelsen för Johannes ante portam latinam (1481) där eftersom dess grundare, Birgitta Henriksdotter (Snakenborg) och Ture Jönsson (Svarte Skåning) och andra av deras släktingar är begravda i det området. I klostermuseet finns även ett broderat bräm som genom sina vapenbilder för Svarte Skåning och Brahe kan ha hört till detta altares textila skrud. ${ }^{745}$

Heliga Birgitta föreskrev inte något Annaaltare, men det finns tre Anna-självtredjebilder kvar och fyra kända altarstiftelser som nämner S Anna. Ett par av dem har redan berörts som hastigast. Det äldsta Annaaltaret fanns i det tidigare diskuterade och av drottning Filippa grundade Anna-koret, invigt $1427 .{ }^{746}$ Reduktionsprotokollet 1540 nämner två olika Annaaltaren, ett i lekfolkets del av kyrkan, "in templo", och ett "in monasterio", dvs. inte "in claustro". Dessa båda Annaaltaren hörde till de hårdast beskattade av kyrkans alla altaren, då 13 respektive 11 mark silver beslagtogs från dem. ${ }^{747}$ Källström tolkar platsbeteckningen "in monasterio" som en placering i brödernas kor, vilket kan ifrågasättas. ${ }^{748}$ Benämningen avslöjar hursomhelst att det hörde till klostrets domäner och inte lekfolkets, vilket är särskilt intressant i relation till drottning Filippas kor. Det koret stod vid gränsen mellan lekmannakyrkan och klausuren, närmare bestämt intill järngallret och nära dörren in till nunnornas konvent. Som sagt användes det till och med vid vigning av lekbröder/systrar. ${ }^{749}$ Dessutom övergick patronatsrätten för detta kapell med tiden till klostret. Det är därför möjligt att det kapell som avsågs med den särskilda beteckningen "in monasterio" var just drottning Filippas Annakapell, eftersom det inte var placerat innanför klausuren men tillhörde klostret. Från Annaaltaret "in monasterio" togs 1540 en kalk och en monstrans med glasbehållare, tillsammans med ospecificerat förgyllt silver. Som tidigare har nämnts togs likaså flera föremål från Annaaltaret "in templo", bland annat ett bröstspänne, ett korallradband, två kransar med tillhörande lad samt en mängd små silverströningar. ${ }^{750}$ Det var två rika altaren.

Det kronologiskt sett andra Annaaltaret i klosterkyrkan var det som grundades 1428 av medlemmar ur familjerna Bielke, Bonde och Vasa. Det var ett altare invigt

\footnotetext{
744 Lindblom 1965 s 236.

745 Fragmentet kommer troligen från ett altarbrun.

746 DV 374.

747 Källström 1939 s 48-50, 143-145.

748 Källström 1939 s 282.

749 DV 698: "Vidare, på martyren sankt Petrus' dag [29/6] insattes två bröder ab extra, det vill säga Jöns Olofsson och Klaus som var klockare (eller vaktmästare i klosterkyrkan) av konfessorn broder Magnus. De förstnämnda stod i drottningens kapell och konfessorn innanför korskranket eller gallret."

750 Smyckena kan ha varit delar av en brudutstyrsel som man kunde låna till bröllop.
} 
till S Erik, S Anna och S Birgitta. ${ }^{751}$ Därefter grundades ytterligare ett altare 1432, "det tredje Anna-altaret", av medlemmar ur familjen Vasa. ${ }^{752}$ Det handlar alltså om tre relativt tidiga och i tiden tätt efter varandra skapade Annastiftelser, vilket också gör det svårt att differentiera dateringen av de tre bevarade skulpturerna. Något altarskåp med scener ur legenden om S Anna och Joakim har inte bevarats. Däremot finns det tidigare nämnda figurbroderade altarbrunet i klostermuseet (Pietas nr 3596). (Bild 37.) ${ }^{753}$ Där framställs legenden om Anna och Joakim och scener ur jungfru Marias barndom. Brunet innehåller även några andra helgon, men eftersom Katarina av Vadstena inte finns med bland dem är det antagligen tillverkat före hennes skrinläggning $1489 .{ }^{754}$ Det är också tänkbart att någon av de tre kronor som räknas upp i inventariet 1595 hörde till detta Annaaltare, liksom någon av de fyra uppräknade kalkarna. ${ }^{755}$

Den ovan ställda frågan om hur många altaren det funnits i Vadstena klosterkyrka kanske aldrig kan besvaras, men det går att komma en bit på väg. Identifieringen av altarnas placering försvåras av den knapphändiga dokumentationen. Diariet ger ibland en fingervisning om att någon begravdes i närheten av en viss person eller plats, eller tillsammans med någon annan. Lägesupplysningen för exempelvis den tidigare nämnda Bo Jonssons (Grip) grav visar sig dessvärre oanvändbar eftersom den kyrka han begravdes i 1386 var en tillfällig träbyggnad vars placering är okänd. Därmed går det inte att lokalisera det Helga korsaltare han stiftade, i den nuvarande kyrkan.

För att tentativt placera in de många altarna i kyrkan ger Robert Bennets katalog över kyrkans gravstenar värdefulla upplysningar, liksom de informationsrika gamla gravkartorna. Förteckningen över altarstiftelser hos Andreas Lindblom har visat sig vara en användbar källa när det gäller altarnas antal. Likaså ger J. F. Martins bild från den gamla sakristians uppställning av bilder före den första 1800-talsrenoveringen av kyrkan viktig information. (Bild 9.) Även de bevarade föremålen i kyrkan och museerna kan bidra med information i sammanhanget. De många skulpturerna och altarskåpen indikerar ett ännu större antal altaren eftersom flera figurer som nu står i ett skåp eller vid ett dorsale är placerade där sekundärt. Separerar man de skulpturer, helgonskåp, altarskåp och predellor som nu är sammanställda 1900-talsrekonstruktioner så får vi ett betydligt större antal altaren som lämnat fysiska spår efter sig. Fem av skulpturerna som avbildas i skåp/dorsalen i Martins bild svarar inte mot någon av de idag bevarade bilderna. Åtminstone tre, kanske fyra, av skåpen i bilden är förkomna. Av de idag bevarade skulpturerna är det fem som har skåp/dorsalen, nämligen de båda Johannes döparen, Jakob d.ä., Katarina av Alexandria och madonnabilden i klostermuseet. Förmodligen är det bara Katarina av Alexandria som står vid sitt ursprungliga dorsale. Jämför man Martins bild och

\footnotetext{
751 Lindblom 1965 s 234.

752 Lindblom 1965 s 235.

753 Brunet är 166,5 cm långt och 17,5 cm högt.

754 Estham 2001 s 119-120, Lindblom et al. 1918 s 87-89.

755 Inventariet nämner tre kronor, en stor och två små, samt fyra silverkalkar och tre paténer.
} 
de bevarade helgonbilderna med stiftelsedokument och reduktionsprotokollet växer listan över visuellt eller textuellt belagda altaren till närmare sextio. Det är också möjligt att kyrkan pryddes av helgonbilder som inte var knutna till ett altare, exempelvis på de omfångsrika bärande pelarna, ${ }^{756}$ vilket Lindblom inte tagit med i diskussionen.

De olika altarnas fördelning över kyrkorummet visar att det finns områden som har olika intensitet, olika laddning, vilket berördes i samband med berättelsen om Kristina från Gärdslätt. Beroende på vilket syftet var med kyrkobesöket kunde olika platser ha olika dignitet och besökas i olika ordning, vilket mirakelberättelsen likaså vittnar om. Även lekmannakapellens många olika helgon fyllde en andlig funktion för besökarna. De många kapellens altarbilder och övriga utsmyckning blev dessutom en viktig del av kyrkorummet, liksom de många dekorativa gravstenarna i kyrkgolvet. Frälset tillkännagav här sin betydelse både i världsligt och andligt avseende. Deras vapenbilder, och kanske också deras färger, kunde användas på altarnas utsmyckning och gravstenarna för att markera identiteten. Som tidigare konstaterats skulle man kunna föreställa sig en blå och gul dominans på utrustningen i Karl Knutssons (Bonde) Helga lekamenskapell, eller rött och gult vid exempelvis Hammerstaättens S Olofsaltare, men det är ett bruk som kvarstår att belägga i detta sammanhang. ${ }^{757}$

\section{Lekfolkets kyrka}

Den medeltida besökaren i Vadstena klosterkyrka mötte en ovanligt rik bildmiljö innanför kyrkdörrarna. Det kyrkorum besökaren klev in i var helt annorlunda jämfört med det öppna och vidsträckta rum som möter dagens besökare. I de flesta medeltida församlingskyrkor fanns bara några få altaren förutom högaltaret i koret, och enstaka gravar för det lokala frälset. I klosterkyrkan omgavs man däremot av kor, altare och frälsegravar vart man än gick. Altarna representerade helgon som kunde bistå vid de flesta bekymmer i livet, och andliga bilder gav tröst inför det hinsides genom avlaterna som de var förknippade med. Här fanns en mängd inbyggda små kapell och mer eller mindre inhägnade kor. Mest framträdande för den som klev in genom portarna var Birgittakoret eftersom det var både stort och placerat nära ingången, och det var här som de flesta pilgrimer nådde målet för sin resa. Dess altarskåp hörde till de större i kyrkan och oljelampor, vaxljus och andra votivgåvor bidrog till att framhäva platsens betydelse. Här rörde sig människor både runt altaret och framför det. I detta kapell fanns troligen den "extatiska” Birgittabilden. Lyfte besökaren blicken mot östra väggen så avtecknade sig Mariakorets altare mot mittfönstrets ljus, ovanför Birgittaaltaret. Möjligtvis stod heliga Birgittas silverskrin upphöjt mellan Birgittaaltarskåpet och Mariakoret, som föreslogs ovan.

\footnotetext{
756 Se exempelvis Nikolauskyrkan i Stralsund https://commons.wikimedia.org/wiki/ Category:Interior_of_St_Nikolai_in_Stralsund?uselang=de\#/media/File:01_Stralsund_ St_Nikolai_027.jpg .

757 Se Hablot 2018 s 55-87.
} 


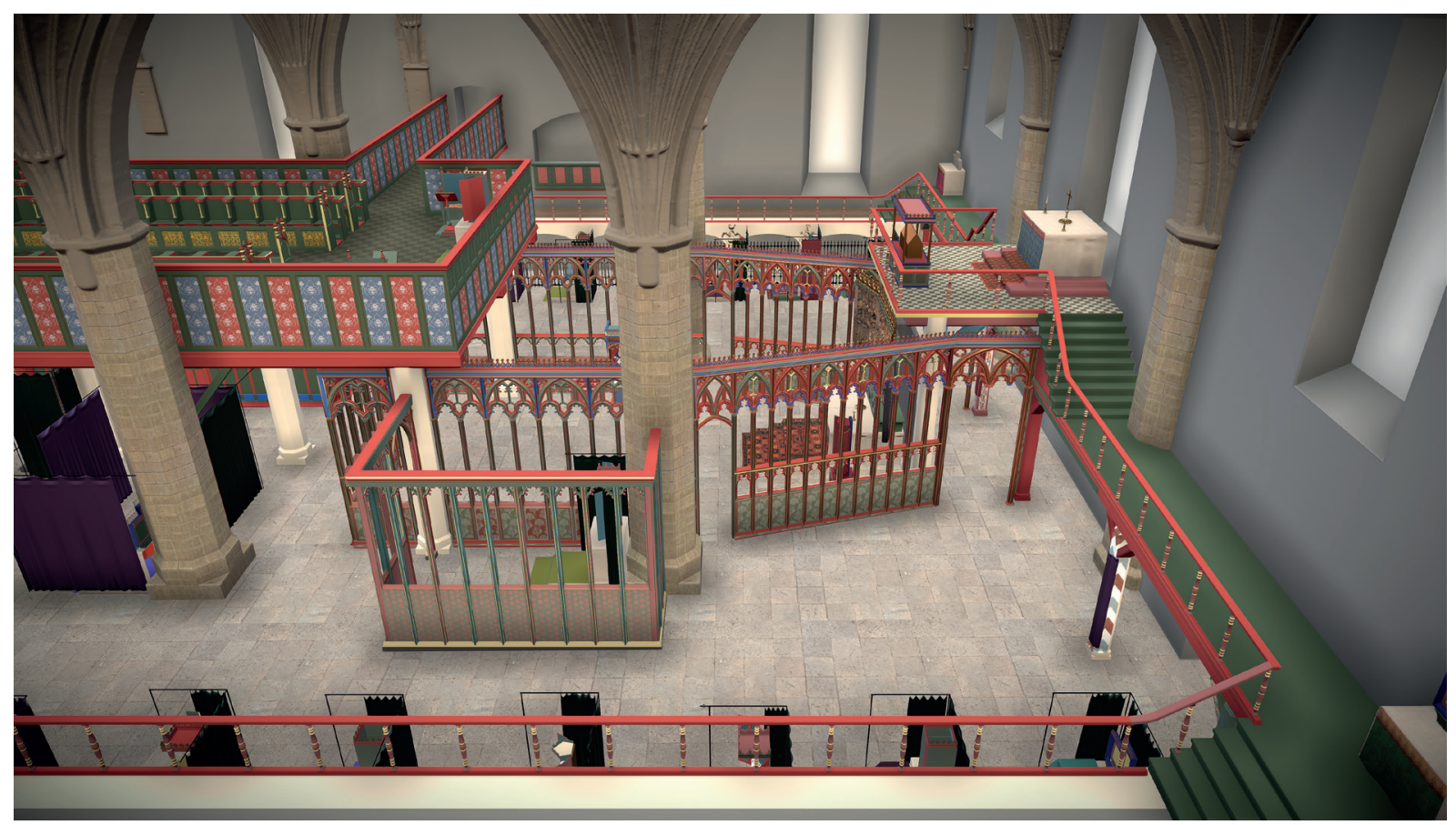

Bild 71. Detalj från digital 3D-rekonstruktion av klosterkyrkans östra delar med nunnekoret till vänster och i mitten Birgittakapellet. Till höger ses hur den östra delen av sidoläktarna leder upp till Mariakoret. I bakgrunden skymtar herrskapsläktaren på den norra sidan. (C) förf. och Carolina Ask.

Kanske stod transportskrinet på baksidan av Birgittaaltaret, så att man defilerade förbi båda skrinen när man passerade bakom altaret. Sina gåvor till jungfru Maria kunde man möjligtvis lämna under hennes kor, dvs. vid östväggen alldeles bakom Birgittaaltaret.

För att ta sig längre mot väster i kyrkan och högkoret gick besökaren förbi ett antal helgonaltaren, placerade i små kapell vid pelarna och utmed sidoläktarna, inhägnade av snidade korskrank eller påkostade sidendraperier. Vid en del altaren läste präster mässa och på de murade sidoläktarna fanns målade vapensköldar för de familjer som hade sina gravar intill. Framme vid järngallret i väst kunde man se magister Petrus gravsten vid den södra pelaren, medan Katarinakapellet befann sig vid pelaren mittemot. I Katarinakapellet kunde pilgrimen betrakta den vackra helgonskulpturen, det dyrbara broderade röda gravtäcket och det guldglittrande röda sammetsskrinet med Katarinas reliker. Även här brann många ljus och lämnades votivgåvor som tack för bönesvar. Ställde man sig mitt emot grinden i järngallret befann man sig mellan magister Petrus grav och saliga Katarinas kor. Sedda från denna position skapade de tolv apostlaaltarnas plogformation en uppåtgående rörelse som avslutades med det upphöjda stora högaltaret, där ljuset från brödrakorets fönster framhävde glansen både i altarskåp och de av pärlor och guld glittrande färgglada altartextilierna. Högkorets sakrala betydelse framhävdes ytterligare av den med ljusbärande änglar krönta baldakin som skapades till Katarinafesten 1489. ${ }^{758}$

758 Fritz \& Elfving 2004 s 33, 35. 
Det var ett mycket rikt utrustat och livfullt kyrkorum som den medeltida besökaren kunde vandra runt i. Det var även ett ovanligt stort kyrkorum för att inte vara en katedral, och det var ett rum fyllt av inbyggda mindre rum och rumsavgränsningar. Det var dessutom ett kyrkorum där frälset, deras status och deras fromma förhoppningar, gjorde sig tydligt påminda. Deras plats blev än mer iögonfallande i detta kyrkorum än i de medeltida katedralerna, eftersom frälsegravar och kapell samlades i kyrkorummets centrala del. För lekfolket skapade detta myller av kapell och altaren en upplevelse väsensskild från besöket i den egna sockenkyrkan. De fromhetuttryck som framställdes i bilderna på de privata altarna var samtidigt bekanta för de flesta eftersom de hörde till tidens fromhetsyttringar. Man kan säga att det specifikt birgittinska i själva rummets gestaltning fick en motvikt och kontextualiserades genom det allmänkatolska bidraget från frälset. Av klostrets invånare märkte kanske inte lekfolket så mycket, mer än när det var tidebönsdags. Då hördes brödernas mörka röster från koret bakom högaltaret, följda av de högt uppe på läktaren klingande nunnornas ljusa röster. 